Portland State University

PDXScholar

\title{
The Home-School Connection: Parental Influences on a Child's ESL Acquisition
}

Catharine Jauhiainen

Portland State University

Follow this and additional works at: https://pdxscholar.library.pdx.edu/open_access_etds

Part of the Applied Linguistics Commons, Bilingual, Multilingual, and Multicultural Education

Commons, Early Childhood Education Commons, Educational Methods Commons, and the First and Second Language Acquisition Commons

Let us know how access to this document benefits you.

\section{Recommended Citation}

Jauhiainen, Catharine, "The Home-School Connection: Parental Influences on a Child's ESL Acquisition" (1997). Dissertations and Theses. Paper 5379.

https://doi.org/10.15760/etd.7252

This Thesis is brought to you for free and open access. It has been accepted for inclusion in Dissertations and Theses by an authorized administrator of PDXScholar. Please contact us if we can make this document more accessible: pdxscholar@pdx.edu. 
THESIS APPROVAL

The abstract and thesis of Catharine Jauhiainen for the Master of Arts in Teaching English to Speakers of Other Languages were presented May 29, 1997, and accepted by the thesis committee and the department.

COMMITTEE APPROVALS:

$$
\text { Marjorie Terdal, Chair }
$$

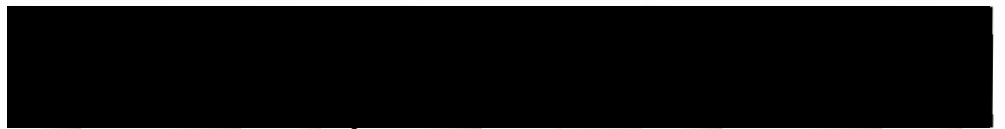

Kimberley A. Brown

\section{Emily de Ya Cruz, Reppesentative of the} Office of Graduate Studies

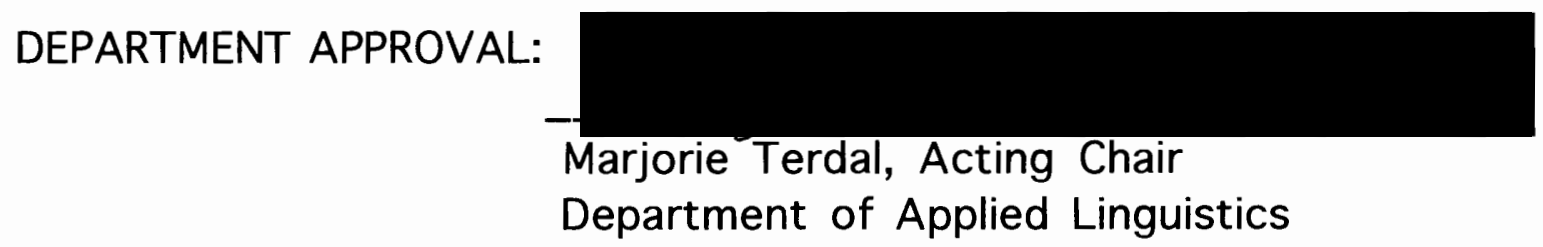

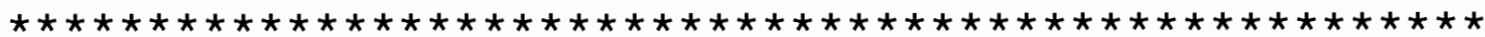

ACCEPTED FOR PORTLAND STATE UNIVERSITY BY THE LIBRARY

by

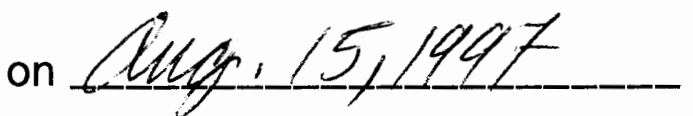




\section{ABSTRACT}

An abstract of the thesis of Catharine Jauhiainen for the Master of Arts in Teaching English to Speakers of Other Languages presented May 29, 1997.

Title: The Home-School Connection: Parental Influences on a Child's ESL Acquisition

Few would dispute the tremendous impact that parents have on the intellectual, emotional, and social development of their children. An important issue in child second language acquisition is whether, or to what extent, parental attitudes and behaviors are associated with the success of language minority children in elementary ESL and mainstream classroom settings. The effects of parental educational values and expectations, and parental perception of ability to assist in the educational journey of their offspring, have been the focus of much research regarding majority language children. However, research exploring the beliefs and behaviors of language minority parents and their relationship to their children's second language acquisition and overall school success has not been nearly as extensive.

Using a quantitative approach, data were collected via a 
questionnaire from twenty-three language minority parents whose children were enrolled in a public elementary ESL program. The thirty-six children were administered two English language proficiency tests, and their first and second quarter grade reports were also collected.

The data generated reveal that parental perception of efficacy appears to be an important element in a child's English reading achievement. Additionally, children of parents who read a magazine or newspaper with some frequency tend to score higher on reading proficiency. The data also indicate that language minority parents value education highly, and expect their children to be diligent with their schoolwork. 
THE HOME-SCHOOL CONNECTION: PARENTAL INFLUENCES ON A CHILD'S ENGLISH SECOND LANGUAGE ACQUISITION

\author{
by \\ CATHARINE JAUHIAINEN
}

A thesis submitted in partial fulfillment of the requirements for the degree of

MASTER OF ARTS

in

TEACHING ENGLISH TO

SPEAKERS OF OTHER LANGUAGES

Portland State University

1997 


\section{ACKNOWLEDGEMENTS}

Many individuals assisted, encouraged, and supported me throughout my graduate education, and particularly during the writing of this thesis. I wish to thank my mother: my first, and best, teacher. As the mother of a young child myself, I am now beginning to grasp the magnitude of love, effort, time, and patience necessary to be a good parent and teacher. I have fond memories of being read to as a child, and I believe that this activity nurtured my life-long love of reading. My mother has always offered her unconditional support in my endeavors. I am grateful to have such a role model.

Throughout my own educational journey, I have been fortunate to have had many wise and effective teachers and professors, whose impact on my life has been far-reaching. Several dedicated professionals will always remain prominent in my mind: Mrs. Haney, Mr. Bruckner, and Professor Toews. In my postgraduate studies, I have been academically challenged and personally encouraged by many fine professors, particularly Kathryn Harris, Kimberley Brown, and Marjorie Terdal. I would like to thank my advisor, Marjorie Terdal, for her meticulous proofreading of my 
thesis, and for her patience and support throughout this lengthy process. I appreciate the efforts of Kimberley Brown and Emily de la Cruz, the other members of my committee, for their willingness to read this document and to offer their thoughtful ideas and suggestions. Professor Mara Tableman offered invaluable insight and redirection with the statistical portion of the data analysis.

This research project would not have been possible without the support of "Karen," the ESL teacher, and "Elena," the migrant education coordinator at the school where the data was collected. These dynamic language educators were instrumental in securing district approval for my research, in identifying and recruiting the study participants, and in establishing liaisons with the eight teachers at the school affected by my presence in their classrooms. To them I owe my heartfelt thanks.

Finally, I want to acknowledge the support of my family. My husband Eric has encouraged me and made me laugh even in the most stressful moments of the writing process. Our inquisitive daughter Sarah provides me with the inspiration to instill an enduring curiosity of learning in her life, and to love, support, encourage, and challenge all "my" children--my future elementary ESL students. 


\section{TABLE OF CONTENTS}

PAGE

ACKNOWLEDGMENTS..........................................................................ii

LIST OF TABLES AND FIGURES..........................................................

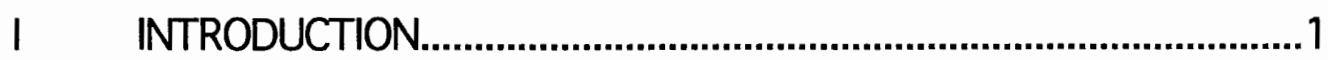

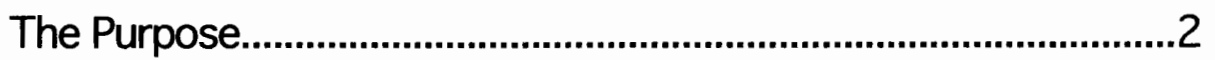

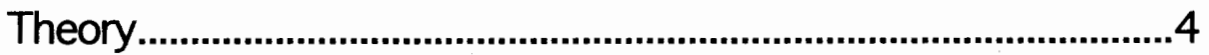

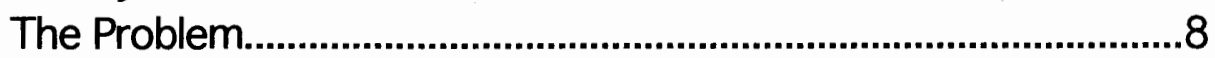

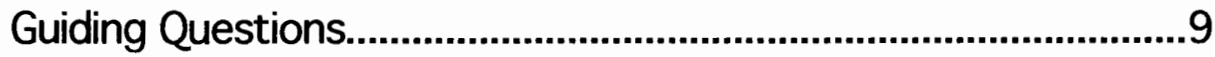

Research Methodology.............................................................10

Definition of Terms....................................................................11

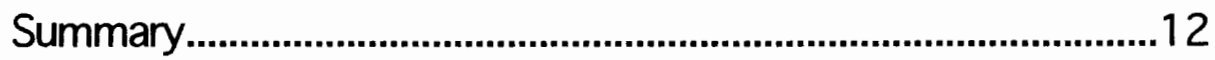

I I REVIEW OF THE LITERATURE.............................................. 14

The Importance of Parental Involvement in a Child's Academic Life.............................................................15

Parental Behaviors and Relationship to Student Achievement: A Focus on Reading and Literacy...............19

The Impact of Demographic and SES Factors on Academic Performance.......................................................31

Parental Attitudes and Relationship to Student Achievement...............................................................40

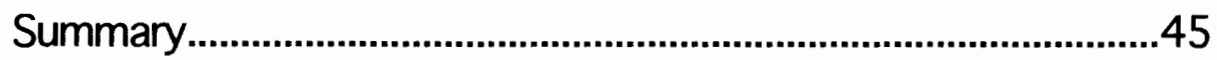

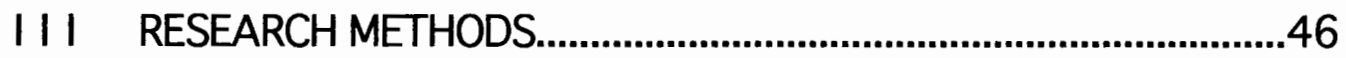

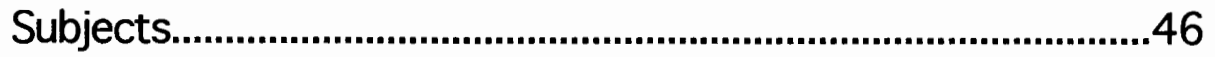

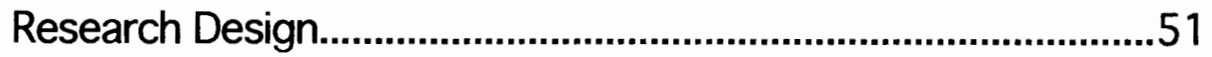

Data Collection Procedures................................................54 


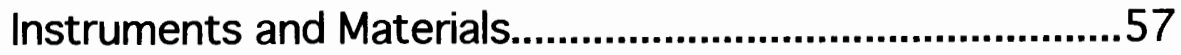

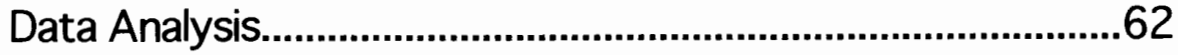

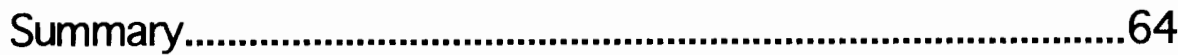

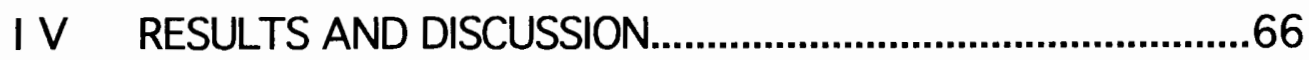

Parental Educational Expectations and Values.............71

Parental Perception of Efficacy........................................72

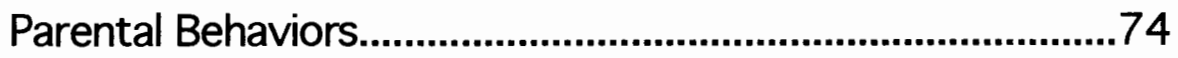

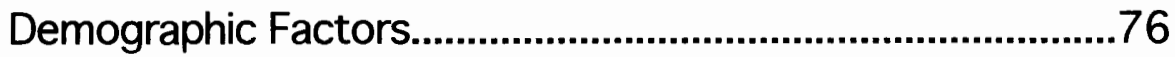

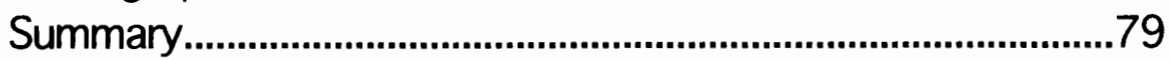

V ANALYSIS, CONCLUSIONS AND IMPLICATIONS..............81

Discussion of Research Questions...................................82

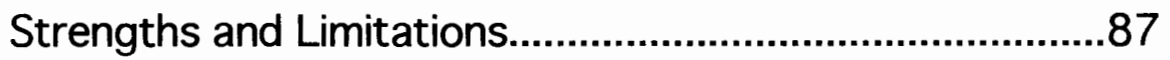

Recommendations for Future Research........................89

Implications for Teachers

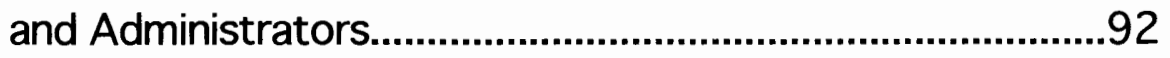

Summary.................................................................................93

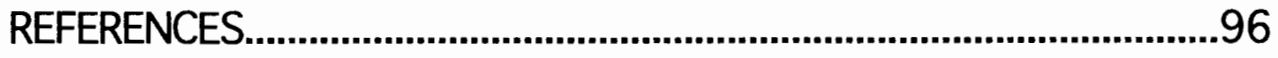

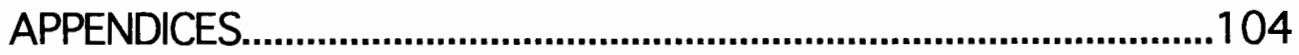

A Invitation/Flyer Sent to Parents.......................105

B Consent Form........................................................107

C Parent Questionnaire--English...........................109

D Parent Questionnaire--Spanish..........................117

E Sample Reading Miscue Inventory.....................125 
LIST OF TABLES

TABLE

PAGE

1 Summary of Parent Questionnaire Responses.....67

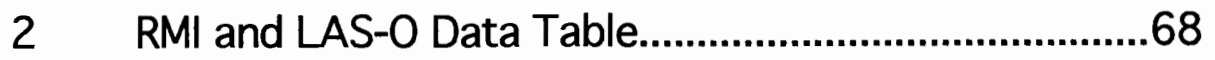

3 Interpretation of Scores for LAS-O........................69

$4 \quad$ Interpretation of Scores for RMI............................69

$5 \quad$ Fisher's Test Formula and Data Analysis..............73

\section{LIST OF FIGURES}

FIGURE

1. Educational Level Completed By Parents...............47

2. Length of Parent's Residence in the U.S.................48

3. Types of Parental Employment..................................48

4. Distribution of Students by Grade Level................50

5. Number of Days Per Week Parent Helped Child with Homework..................................................................74

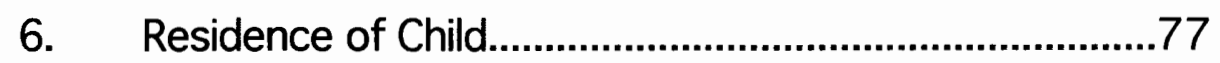




\section{CHAPTER 1}

\section{INTRODUCTION}

An important issue in child second language acquisition research is whether, or to what extent, parental attitudes and behaviors are associated with the success of Limited-EnglishProficient (LEP) children in elementary ESL and mainstream classroom settings. The effects of parental educational values and expectations, and parental perception of ability to assist in the educational journey of their offspring, have been the focus of a large body of research regarding majority-language (and often monolingual) children (see Comer, 1984; Davies, 1991; Kellaghan, Alvarez, Sloane \& Bloom, 1993; Lareau, 1989; Silvern, 1985). However, research exploring the beliefs and behaviors of minority language parents and their relationship to their children's second language acquisition and overall school success has not been nearly as extensive.

This thesis will explore the impact of the home culture and environment on the language acquisition process of LEP students, investigating which actions and attitudes of parents make a difference in the child's overall achievement in ESL and 
mainstream classes. All of the participants in this study speak Spanish as their native language. The students are enrolled in a public elementary school, and each child is in an ESL class as well as a mainstream class. Many of the teachers at this elementary school speak Spanish as either a first or second language.

\section{THE PURPOSE}

The issue of parent participation and its importance in elementary ESL education first came to the attention of this investigator while engaged in teaching and tutoring practicums. The teachers of these elementary language minority (LM) students conveyed to this researcher that involvement and support of the parents is crucial to the academic success of children enrolled in ESL classes. These language educators asserted that many of the more successful students had parents who were active participants in their children's academic lives. Gardner (1968, 1985) emphasizes the importance of both active and passive parental roles in second language acquisition. He describes the active role as one in which the parent encourages the child in a variety of ways to acquire the second or additional language (L2), such as monitoring the child's language study, encouraging the child to make his/her best effort in the second language school setting, and reinforcing his/her academic progress in general 
terms. Gardner attributes the passive role of parents as being more "subtle" and indicates that this subtle influence is perhaps one of which parents are unaware. Gardner describes the passive parental role as those attitudes of the parents toward the community of the language their children are learning. A crosscultural study conducted by Lambert and Klineberg (1967) demonstrated that in a variety of cultures throughout the world, child attitudes toward other ethnic and language groups were strongly influenced by their parents. In a study of English and French Canadians, Gardner (1968) asserts that “children's attitudes...are highly related to the attitudes of their parents, and it seems reasonable to assume that the child reflects the attitudinal atmosphere of his home" (p. 143).

Other teachers in the investigator's acquaintance related that even non-literate parents can be influential in the ESL acquisition process, by telling their children that education is important, by assuring them they have the ability to succeed, by asking their children to explain completed homework assignments to them, and by implementing teacher recommendations. These assertions are supported by the literature (see Gardner, 1968; Lareau, 1989; Tizard, Schofield, \& Hewison, 1982). 


\section{THEORY}

Few would dispute the intuitively appealing notion that parents exert a profound influence upon their children's lives. Potter (1989), in his study of parent participation in language arts programs and its effect on student achievement, holds that "Parents are the child's first and most important teachers and will probably have the greatest impact on a child's development...it is essential that supporting a good relationship between parents, child, and teacher should be a priority" (p. 21). Potter's study also explores the notion of parents as coeducators of their children, and emphasizes the duty of the teacher and school administrator to nurture parent participation in the child's academic life. This view that it is the responsibility of the teacher and school administrator to reach out to parents is prevalent throughout the literature (see, for example, Cochran \& Woolever, 1983; Bronfenbrenner, 1978; Blackie, 1991; Comer, 1984). Potter offers several explanations as to why parents may not be involved in the educational process of their children, and he illustrates a four-part model for encouraging parent participation. Three schools are described which have successfully incorporated Potter's model for reaching out to parents and expanding their role of coeducator beyond the home. He states that increased academic achievement of the children, more open lines of communication between school and community, and a 
parental sense of pride and ownership were the products of the model's use in these three schools.

Researchers from fields such as applied linguistics, education, sociology, psychology, and anthropology have explored the impact of a variety of factors upon the academic learning experience of children. Variables such as parental attitudes, behaviors, socioeconomic status (SES), educational/occupation expectations, IQ, gender of child, sibling rank, and educational level attained by the parent(s), have been considered important in their relationship to the academic success of children (see Hewison, 1982, 1988; Olmsted \& Rubin 1983; Bloom, 1985; Eagle, 1989; Clark, 1983, 1990, 1993).

Olmsted and Rubin (1983) conducted several in-depth studies linking parent behaviors to child achievement. The researchers gathered data from the parent participants through direct observation and from personal interviews. The data obtained from the parents were then analyzed in relationship to the child achievement test scores. Olmsted and Rubin found that four parental/family environment factors seemed to positively influence child achievement: language stimulation, educational/reading activities, educational/occupation expectations, and reinforcement of expectations. Additionally, Olmsted and Rubin found that both language stimulation and 
parental educational/occupational expectations "were significantly related to both child reading and math achievement scores" ( $p$. 322). In a later study using the same data, the researchers found that parental socioeconomic status (SES) influences the home environment significantly, but that it influences parent involvement in the child's academic life to a lesser degree. The relationships among SES, parent involvement in a child's school, and child academic success will be explored further in the review of the literature in Chapter II.

The home environment has long been thought to exert a critical influence on the academic success of children (Hansen, 1969; Comer, 1984; Bloom, 1985; Laosa, 1983; Dolson, 1985). Researchers have explored a wide variety of hypotheses and variables, and have employed many different methods of data collection in an attempt to explain the functional relationship between home and school. Kalinowski and Sloane (1981), drawing upon earlier research by Bloom, assert that "the first ten years of life is the period of most rapid development for the human characteristics most crucial in school success" (p. 85). While family background characteristics such as income and educational level have received much attention, in more recent years, researchers have focused greater energy on investigating family attitudes and behaviors in relation to a child's school achievement 
(Clark, 1993; Okagaki, Frensch, \& Gordon, 1995; Scott-Jones, 1984). Clark's (1993) study of 1,141 urban third-grade students explored whether certain parenting practices correlated with high academic achievement on the part of their children, and whether those practices were related to the parents' ethnic identity, educational level, and family structure. Clark divided his student sample into a group of high-achievers (those scoring at or above the 50th percentile on the CTBS) and low-achievers (those scoring in the 25th percentile or less on the CTBS). The students were predominantly Hispanic, Asian, Black, or other non-Anglo. The parent data were gathered through a questionnaire sent home with the students. Forty percent of the parents returned the survey; 156 from the parents of the high achievers, and 304 from the parents of the low achievers.

Clark's data show that there was no significant difference between the behaviors of parents of the high-achieving students and behaviors of parents of the low-achieving students on many of the variables he investigated. However, he discovered that parents of the high-achieving students were more involved in home learning activities, such as modeling of reading and writing, and their children invested more time in doing their homework. The parents of the low achievers spent more time helping their children complete homework assignments, and in language minority homes, 
the parents of the low achievers spoke English at home more often than the parents of language minority high achieving students.

Clark also found that two sets of family process variables were significantly related to higher achievement: parent's press for academic achievement, which included a parent's expectation for the child's education, and family circumstances and resources for achievement, which included parental perception of efficacy-how to help in their child's academic progress. Clark notes that despite the apparent relationship between achievement and family resources, the higher-achieving students encompassed a broad spectrum of family backgrounds. Clark believes that most parents of both high- and low-achieving students practice at least a few of the positive behaviors which contribute to academic success, but “...to be academically successful, students apparently needed their parents (or other adults) to expose them to an array of additional support behaviors" (p. 103).

\section{THE PROBLEM}

As this researcher's interest in the role of parents in the ESL acquisition of their children increased, attempts were made to find support in the literature for the anecdotal statements offered by elementary ESL educators. A review of the literature reveals that there have been few recent studies regarding minority language 
parental attitudes and behaviors, and their impact upon the second language learning process of their children. If certain parental attitudes and actions can be said to have a positive impact in a child's language learning experience, perhaps teachers, administrators, and others involved in the educational process may wish to encourage and promote these identified attitudes and actions. It is the hope of this investigator that the study undertaken in the following pages will make a contribution in this area.

\section{GUIDING QUESTIONS}

The following questions are explored in this study:

1. Which parental educational expectations and values are associated with their children's achievement in ESL acquisition?

2. Which parental behaviors (e.g. modeling of reading) are associated with their children's success in ESL acquisition?

3. Is parental perception of efficacy (the degree to which parents of language minority children view themselves as being able to assist their children in school) related to their children's ESL and mainstream classroom achievement?

4. What demographic factors influence the Limited-EnglishProficient (LEP) child's achievement in acquiring English?

To respond to these guiding questions, data were collected in 
several phases. A public elementary school was selected as the research site, and the parents of the children enrolled in the ESL program were contacted by letter and by phone. A meeting at the school was arranged for the purpose of administering a questionnaire to the parents. Items on the questionnaire encompassed each of the areas presented in the guiding research questions. The second phase of the data collection involved the administration of two tests of language proficiency to the children in the ESL program whose parents had participated in the survey, and the third phase entailed the collection of first and second quarter mainstream classroom grade reports/evaluations.

\section{RESEARCH METHODOLOGY}

This study incorporates a multivariate research design. The independent variables include 1) parental attitudes and behaviors, 2) degree of parental efficacy, and 3) demographic factors. The dependent variables are 1) the students' scores on the a) Reading Miscue Inventory (RMI) and b) Language Assessment Scale-Oral Proficiency (LAS-O) tests, and 2) their first and second quarter grade reports.

A questionnaire (see Appendices $C$ and $D$ for the English and Spanish versions) was used in order to gather data to respond to the research questions. This questionnaire was adapted from an 
earlier study conducted with Mexican-American parents and their elementary school-aged children (Okagaki, Frensch, \& Gordon, 1995). The questionnaire was completed by parents of children in a public elementary school ESL program. The LAS-O and RMI tests were administered to the children by this researcher.

\section{DEFINITION OF TERMS}

CTBS: Comprehensive Test of Basic Skills

ESL: English as a second language.

Heritage language : one's first, or native language. This term is used in Canada to describe the native lanquage of Canada's indigenous peoples.

$\underline{L}$ : language one, or the native language.

L2: language two, or the second/additional language. Language minority (LM): refers to individuals within a particular society who do not speak the language of the dominant language group as their native/first language.

LEP: an acronym for Limited-English-Proficient, which refers to individuals with limited proficiency in the English language.

LAS-O: the Language Assessment Scale of Oral proficiency in English. This is a frequently used standardized test employed by school districts to determine a student's level of 
oral proficiency in English. The Pre-LAS is used for testing kindergarten students, while the LAS-O is used for students in grades 1-5.

RMI: Reading Miscue Inventory. This test assesses reading proficiency in English.

SLA: second language acquisition.

Socioeconomic status (SES): generally, consists of several factors such as family income, number of certain possessions (such as major appliances), educational level of parent(s), father's occupational status.

\section{SUMMARY}

The purposes of this study are as follows: 1) to provide documentation regarding the influence of parental attitudes and behaviors on child ESL acquisition, and 2) to provide teachers and administrators with an awareness of which parental beliefs and behaviors appear to have a positive impact on the second language learning process, so that these identified attitudes and actions might be promoted and encouraged.

The succeeding chapters of this thesis are composed of a review of the relevant literature regarding the parental role in the educational process of children (for both dominant language/monolingual children and minority-language children), the 
importance of parental involvement, the relationship of parental modeling of certain behaviors to the child's academic achievement, the influence of demographic factors and socioeconomic status, and the relationship between parental perception of efficacy and the child's academic performance (Chapter II). The research methods used for this study are outlined in Chapter III, including the research design, the subjects and site school, the data collection procedures, and data analysis. The results of the data analysis and discussion are included in Chapter IV, along with many of the tables supporting the discussion. Further analysis and conclusions are presented in Chapter $\mathrm{V}$, as well as a discussion of the research questions, strengths and limitations, implications for teachers and administrators, and recommendations for future research. 
CHAPTER ॥

\section{REVIEW OF THE LITERATURE}

Education within a formal setting and specified building did not exist much before the twentieth century for the majority of children in the United States (Coleman, 1987). For many young people, the activities of the household, farm, or small town provided the education or training needed to be self-supporting as adults. The power and importance of the home environment was formidable.

Although society has changed radically since the early years of this century, and the structure of families has also changed, the home environment remains a dominant, molding force in the life of a young child (Coleman, 1987; Bloom, 1985). Olmsted postulates that ...a child's chances for success in

later life are maximized when both the home and the school are involved in the child's education. Moreover, since schools in America operate within a traditional middle-class framework, children from low-income and minority families have the best chance at a smooth transition from home to school when there are strong home-school connections. (1991, p. 221)

This chapter will examine the importance of parental involvement in a child's academic life, and the relationship 
between parental influence/involvement and achievement. The impact of demographic and socioeconomic factors on a child's academic performance will be explored. The influence of parental attitudes and behaviors and their relationship to student achievement will also be investigated. Much of the literature reviewed in this chapter focuses on ethnic minority/language minority children, although the impact of similar research among majority/dominant language children and families cannot be overlooked.

THE IMPORTANCE OF PARENTAL INVOLVEMENT IN A CHILD'S ACADEMIC LIFE

The role of the home culture and environment in a child's acquisition of language and educational development should not be underestimated (Caplan, Choy \& Whitmore, 1992; Chavkin, 1987; Figeuroa, 1993). Children who are not proficient in English frequently encounter failure and disappointment in the public school system (Cummins, 1986; Delgado-Gaitan, 1991; Laosa, 1983; Trueba, 1988). Administrators, policy makers, and teachers must attempt to cultivate and nurture an open, communicative relationship with the parents of language minority students as part of the process of providing meaningful educational opportunities to all children (Violand-Sanchez, 1991). A review of the literature 
reveals that the importance of parental involvement and its relationship to school success in children is a belief common to many. Literature in ESL instruction for children, relying upon conclusions of first language acquisition studies, frequently begins with the premise that parental participation in the child's journey of second language acquisition is vital (Berryman, 1982; Caplan, et al., 1992; Figueroa, 1993; Goldenberg, 1989; Torres, 1984). One must be aware of potential dangers in transferring conclusions from research involving majority language or monolingual children to a second language learning context. However, compelling evidence exists to adopt some of the premises of educational research in general to investigate the role of parental attitudes and behaviors of language minority children in an American public elementary school ESL setting.

Mayeske, (1973) in his monumental study of American students, states "...the crucial factor in achievement was not so much the presence or absence of parents or parental surrogates as the nature of their involvement in the educational process" (p. 14). In teacher lounges of elementary schools around the country, educators share anecdotes regarding students who have made improvements in their grades, students who are "achievers," students who seem interested not only in learning, but in learning well. A common denominator in the lives of such students is often 
the active participation of a parent in the educational life of the child. Other researchers have demonstrated that parent influence on a child's school success is quite often significant (Chavkin, 1987; Collazo-Levy, 1983; Comer, 1984).

The notion of parent involvement or parent influence has been defined in various ways. Parent involvement includes activities such as participation in the school's parent-teacher association (PTA), attendance at school-related functions such as Open House or Back-to-School Night, attendance at parent-teacher conferences, and volunteering at the school in various capacities (Epstein, 1986). The realm of parent influence is somewhat more elusive, but has been described as exerting pressure on their children to complete their homework and to attend school regularly, holding high but realistic expectations for completing a certain level of schooling, modeling of specific behaviors in the home (such as literacy activities), communicating to the child the value of learning, self-discipline, and hard work, and exhorting their children to do their very best in all endeavors, educational or otherwise (see Bloom, 1985; Becher, 1984; Clark, 1990; Lareau, 1989).

Many researchers believe that public schools have not seriously promoted the involvement of parents with limited English skills (Delgado-Gaitan, 1987; Simich-Dudgeon, 1993; Violand- 
Sanchez, 1991). Simich-Dudgeon argues that teachers and administrators need to be trained in cross-cultural skills, and in how to initiate and nurture communication with parents who are not proficient in English. Many parents from Hispanic and Asian cultures view teachers and school personnel as the "experts." Members of some cultures fear that to contact the school or to suggest their own participation in school life would show disrespect or interference (Marin \& Marin, 1991; Caplan, et al., 1992). Additionally, Simich-Dudgeon asserts that many parents who are not proficient in English feel that they cannot help their children or assist at the school in a meaningful way.

In an attempt to increase involvement of language minority parents of K-12 students, Simich-Dudgeon implemented a threeyear program for training parents from four language groups (Spanish, Vietnamese, Khmer, and Lao) in home-tutoring strategies. The three components of the project were: training for teachers in techniques for involving parents, parent training, and curriculum development. The families participating in the project used homelearning lessons/activities developed by the teachers. SimichDudgeon found that the students made significant gains from pretest to post-test on all measures of the SOLOM English language proficiency test, which evaluates comprehension, fluency, grammar, vocabulary, pronunciation and writing. Additionally, 
parent contacts with the school increased during the project, and parents reported greater satisfaction with the school and their role as coeducators of their children.

Research on family processes conducted by Kellaghan, Alvarez, Sloane \& Bloom (1993) indicates that a child's home environment and culture have a very strong influence on how well a child performs in school, and also on the amount of schooling a child ultimately obtains. If the family's approach to education and to life diverges greatly from that of the school, children often have difficulty integrating these facets of their lives, and may not complete a sufficient level of schooling (Olmsted, 1991; Silvern, 1988). Kellaghan, et al., (1993) assert that what parents do at home to encourage and support learning has a powerful, independent effect on children's achievement. The authors note that cultural identity and socioeconomic background alone do not determine a child's school success. Additional discussion of socioeconomic and demographic factors will occur later in this chapter.

\section{PARENTAL BEHAVIORS AND RELATIONSHIP TO STUDENT} ACHIEVEMENT: A FOCUS ON READING AND LITERACY

Epstein (1986) obtained data on students' achievements and relationship to parental involvement at home and in the classroom. Some teachers participating in her study reported using several 
techniques to emphasize parental participation with reading and books. These teachers asked the parents to read to their child or listen to the child read; encouraged the parents to take their child to the library; and sent reading materials home with the students to use with their parents.

Using a small sample of these urban language minority students, Epstein investigated whether the fall and spring achievement scores in reading for students whose teachers stressed parental involvement were different from the reading achievement scores of students whose teachers did not stress parental involvement with reading at home. Epstein discovered that the students whose reading achievement scores made greater gains over the course of one school year were the students whose teachers had promoted parental involvement in literacy-related activities at home. She concludes:

The evidence is clear that parental encouragement, activities, and interest at home and participation in schools and classrooms affect children's achievements, attitudes, and aspirations, even after student ability and family socioeconomic status are taken into account. Students gain in personal and academic development if their families emphasize schooling, let the children know they do, and do so continually over the school years. (1987, p. 120)

Several questions remain unanswered by Epstein's study. She does not address whether the teachers whose students made 
greater gains in reading were more interested in their students' success, or whether they projected a different attitude toward the students and their reading activities than did the teachers whose students did not progress as much in reading achievement. In addition, one wonders whether the children's reading results would be similar if the teachers who did not emphasize parental involvement were encouraged to do so, and reading tests were administered to this group of students after one year of stress on parental participation in reading endeavors at home.

The results of Hewison's (1980) studies in London on the influence of parental involvement and reading attainments of children aged seven to eight years merit discussion. The purpose of this study was to explore whether reading achievement within a homogeneous working-class population could be related to differences in the home environments of the students. Attitudinal, cultural, and demographic factors were examined. A primary interest of the researchers was to attempt to define the parental behaviors and the daily interaction with the child.

Parent interviews were conducted which included the topics of attitudes toward the child's education and parental assistance with reading at home. The students' reading achievement was measured by two standardized reading tests. IQ tests were also administered to each child participating in the study. 
In each of the three studies, the element found to be most strongly associated with accomplishment in reading was whether the parent consistently listened to the child read. Hewison emphasizes that listening ("coaching" is the term she uses) to a child read is different from reading aloud to the child. Reading scores between the coached and non-coached children differed by nearly one standard deviation. Hewison expected to find a significant relationship between IQ and reading scores, and this was supported by the data. Strong relationships between IQ and reading score, and IQ and coaching were also revealed. Hewison performed a multiple regression analysis, and discovered "...that the IQ differences ...were insufficient to account for the superior reading attainments of the coached children" $(1980$, p. 212). In addition, she found that reading achievement and amount of assistance provided at home were significantly related. Hewison asserts that the relationship between students' success in reading and parents hearing their children read remains significant even after IQ effects and differences among the four schools in the sample are considered.

An ethnographic study conducted by Goldenberg (1987) of nine low-income Hispanic parents' contributions to their first-grade children's reading skills examined, among other variables, aspects of the students' home environment. Goldenberg inquired as to the 
parents' perceptions of their child's interest in reading, how much education they expected their children to attain, and the value parents placed on their child's academic achievement. He also assessed the availability of reading material in the home and the amount of reading done by the parents. Goldenberg cites these dimensions of home culture as ones which may be important in a child's reading development.

All of the participants in the study were native speakers of Spanish. The parents of both the higher-achieving students and the lower-achieving students expressed the same levels of expectation for their child's achievement. Goldenberg concluded from his data that parental reading habits and availability of literacy materials, and parents' attitudes toward their children's academic success bore a significant relationship to their children's success in firstgrade reading.

Goldenberg links the success of two of the four children placed in the upper three of six reading groups directly to parental assistance. The parents of these children spent time consistently, usually daily, working on reading, writing, copying letters, and sounding out words. The parents of one child became involved in their child's reading when the teacher alerted them to his lack of progress. Within a very short time of the parents' participation in reading assignments at home, this child improved dramatically, 
moving from the lowest of six reading groups to the third highest.

The mother of the second child spent several hours in reading exercises with her daughter each day, without any prompting from the school teacher. The mother's own level of education was through sixth grade, and she was anxious for her child to learn to read, write, and do well in school. Goldenberg indicates that this child reflected her mother's attitude toward learning to read and toward school achievement. He states that the mother not only reinforced what the child was learning in school, but also introduced new letters and sounds at home, in advance of the school's reading curriculum. This additional instruction became apparent when the child excelled in the read-aloud sessions in school and on the end-of-book tests administered by the reading teacher. When asked where she had learned the new letters, the child replied that her mother had taught her. Both Goldenberg and the reading teacher believed that the efforts of the parent reinforced the lessons at school, and in so doing, prevented this child from falling below the other members of her reading group.

Most parents, teachers, and the general public consider "learning to read" the most important educational objective of our public elementary schools (Silvern, 1985). However, despite the high regard with which learning to read is held, many children from both dominant language and minority language homes fail to achieve 
an acceptable literacy level (Comer, 1984; Cummins, 1986).

Silvern suggests the promotion of parent involvement in the reading process at home to encourage reading achievement. He states "Reading to the child is the best-known, most researched and most frequently recommended parental practice that is significantly related to positive attitudes toward reading and reading achievement" (p. 44). Hewison's (1980, 1982, 1988) studies show that listening to the child read aloud, which she terms "coaching," can be just as effective in developing reading proficiency. This is particularly important for the non-literate parent, who may feel that he/she is not able to offer assistance in helping the child learn to read. Silvern asserts that the availability of literacy materials in the home contributes to higher achievement levels in reading. Research indicates that

...when parents themselves read and model the reading process, their children have more positive attitudes toward reading and higher achievement scores than children whose parents do not read (Silvern, 1985, p. 48)

Hansen (1969) and Caplan, Choy, and Whitmore, (1992) support this notion of the importance of parental modeling of reading.

A study of the academic achievement of Indochinese refugee children was conducted by researchers at the University of Michigan (Caplan, et al., 1992). These researchers found that the high level of academic achievement of these language minority 
children could be traced to a home environment that supports education, and to strong family values about the importance of learning. The authors of this study advise that while some of their findings are culturally specific, "others point to the pivotal role of the family in the children's academic success" (p. 36). At the time the research was conducted, these children had been in the U.S. for an average of three-and-a-half years, and were attending schools in low-income metropolitan areas. These families possessed few, if any, English language skills upon their arrival in the United States.

Data were gathered from the parents and children through interviews in their native languages, test scores, and transcripts. The interviews included twenty-six questions related to core values of Asian culture. The refugee children were distributed fairly evenly throughout grades K-12. With the children's mean grade point average at 3.05 , most students were earning a $B$ average. Only four percent of the students in this study were earning below a $\mathrm{C}$ average in school. These students placed just above the national average (54th percentile) on the standardized California Achievement Test.

Caplan, et al. found that specific parental practices and values were related to academic achievement. Reading aloud to the children was reported by 45 percent of the refugee families, either 
in their heritage language, or in English. Of these families, the children's mean GPA was 3.14 , in contrast to the mean GPA of 2.97 in families where parents reported that they did not read aloud to their children. The researchers state "...It is important to note that the effects of being read to held up statistically whether the children were read to in English or in their native language" (p. 40). Additionally, the researchers claim that when families engage in reading and literacy activities at home, the distinction between school and home becomes blurred. Within the context of the family environment, "...learning is perceived as normal, valuable and fun" (p. 40).

Caplan, et al., conclude from their interviews with these families that schoolwork dominated week night activities in the home. The parents and students rated "love of learning" most often as the factor accounting for academic success. These refugee families believed strongly in their ability to design their own future, and emphasized education as the key to obtaining economic success and social acceptance. The authors note that "the most successful Indochinese families appear to retain their own traditions and values" (p. 41). The authors hold that schools must reach out to involve language minority parents in the educational process of their children, and in establishing such contact, must identify "cultural elements that promote achievement" (p. 42). 
Tizard, Schofield, and Hewison (1982) followed their previous study (Hewison \& Tizard, 1980; discussed earlier in this chapter) of parental effects on children's reading attainment with an additional two-year study of elementary schoolchildren who received extra practice at home in reading. Tizard, et al., designed their study so that every child in two randomly chosen elementary classes at six randomly selected schools in a multi-ethnic urban school district, was heard reading at home from books selected by the class teacher on a regular basis. The researchers state that the primary purpose of the study was to determine "...if there was a causal relationship between active parental help and reading performance" (p. 2). All children in the project classes were heard reading books aloud at home. This practice was evaluated against two control groups; the first, a group of children who were given extra reading help by a qualified tutor at the school, and the other a group of children within each project school and at different schools in the district who did not receive additional tutored practice with reading. Tizard, et al note from their previous work that perhaps nearly half of the control group children may have received assistance with reading at home, and no effort was made on the part of the researchers to eliminate this possibility, for ethical and practical reasons. Tizard, et al. state:

It follows that the study can only provide a conservative 
estimate of the importance of parental help as a determinant of reading performance, and this would seem to strengthen the significance of the findings. (1982, p. 13)

The participants ranged in age from six to eight, and the study included 1, 867 students over the two-year period. The children were tested prior to the beginning of the study, and again at the end of each school year using a series of standardized reading proficiency tests. After the first year, the children who received reading help at home had higher mean scores on the reading proficiency tests than the children in the control classes. For the groups which received tutoring help on the school premises, the results were split--one group did not test significantly higher on the reading tests, and one group tested significantly below the others. At the conclusion of the second year, the children were tested again, and the children who received the extra help from parents in reading at home tested significantly higher than the other control groups. Once again, the results for the students who received the tutoring help at school were mixed. One group scored higher, but not significantly so, than the other.

From their data, the researchers conclude that there is evidence to support a causal relationship between parents listening to their children read and the child's reading attainment. The effect of parental assistance in reading was observable in children 
of all initial proficiency levels, and that “...early reading

performance was an extremely powerful predictor of subsequent attainment" (p. 7).

This study has several important implications for teachers and school administrators. The fact that some children in this study had parents who were themselves either non-literate in English or non-literate in their native language, did not hinder the reading improvement of their children in English. Secondly, parentteacher collaboration can be successful with non-literate or nonEnglish speaking parents. Most of the parents who participated in the study expressed great satisfaction at being involved in a reading partnership. The children who received parental help performed significantly better than comparable children who did not, and the children who received tutoring with a reading specialist on the school premises "...did not produce improvements in attainment comparable in magnitude with those obtained from the collaboration with parents" (p. 14).

Three years after the completion of the above-mentioned study, Hewison (1988) sought to determine the long-range effects, if any, of parental help on reading proficiency. Data were obtained from year-end reading tests of all but 48 children from the earlier experiment when they were approximately eleven years old. Hewison reports that the children from the groups who had received 
parental help in reading at home still performed significantly better on the reading tests than those from the other groups. She concludes that there appears to be a long term benefit for the children who received the help of parents at home, regardless of their initial reading level when the project began. There also appeared to be no residual benefit in reading attainment for the children who received the tutoring help at the school sites.

THE IMPACT OF DEMOGRAPHIC AND SES FACTORS ON ACADEMIC

\section{PERFORMANCE}

The disparity in academic performance among children from different minority groups enrolled in the American school system has been the focus of a large body of research (see Clark, 1983; Comer, 1984; Lareau, 1987; Trueba, 1988; Wong Fillmore, 1990). As Hoffmann notes, the definition of school success is construed narrowly.

The idea of what constitutes success appears to be applied in the same way to all children, majority and minority, yet it tends to be defined in terms of traditional, middle-class values deduced from measured school tests, and thus reflecting majority-group standards. (1991, p. 133)

Although some families fail to provide an adequate home environment, most parents, regardless of socioeconomic status or cultural identity, love and nurture their children. Socioeconomic 
status (SES) factors usually include the educational level of the father, family income, father's occupation, and more recently, mother's educational level and occupation (Hansen, 1969; Coleman, 1987).

Several researchers have argued that the type of socialization, child-rearing and skill development of certain minority groups appears to be different from the framework children need to experience success in mainstream American schools (Wong Fillmore, 1990; Okagaki and Sternberg, 1994; Trueba, 1988; Delgado-Gaitan, 1991). In an ethnographic and observational study conducted by Wong Fillmore (1990) of five different racial and ethnic groups, the issues of how child-rearing practices in the home affect school performance are explored. Wong Fillmore asserts that in the Hispanic families observed in the study, parents believed that each child was born with unique characteristics, which parents guided, but did not control. The children in these families were described as respectful, cognizant of the value of hard work, cooperative and patient. Yet these children still did not prosper in mainstream American schools.

From her observations, Wong Fillmore concludes that the middle-class values and models of learning experienced at home in children from mainstream Appalachian families and ChineseAmerican families are more closely related to the culture of the 
school than what children from Mexican-American, AfricanAmerican, and White working-class children experience. She states that children from the latter groups tend not to perform as well in school because their socialization has emphasized patterns of social behavior, not patterns of literacy. In the latter cultures, children learn more by observation and imitation of their elders than from direct instruction; a child's individual rate of development is emphasized, rather than keeping up with other children.

Wong Fillmore asserts that early-childhood enrichment programs frequently attempt to "better socialize children so they will fit into the mainstream" (p. 134). She disagrees strongly, stating these programs

...gain little...if they cause their parents to lose confidence in their child-rearing abilities. Consider the message they convey to parents: You are inadequate; you are doing a poor job preparing your children for school; there is something wrong with your culture. Such messages cannot be good for parents--or for their children. (1990, p. 134)

Wong Fillmore highlights the notion that it is essential for early childhood education programs focusing on racial or linguistic minorities to nurture the parental perception of efficacy--how the parents view their ability to help their children succeed in the mainstream American school system. Other researchers support the importance of encouraging a strong parental perception of 
efficacy (Caplan, et al., 1992; Delgado-Gaitan, 1991; Okagaki, Frensch, \& Gordon, 1995). Wong Fillmore believes that it is very important for minority children to be firmly established in the core values of their primary culture, and in their heritage language, where applicable, in order to enhance their chances for successful adjustment in a typical American classroom.

In discussing sociodemographic variables as they relate to schooling attainment level, Laosa (1983) maintains that SES variables should be examined individually, not as a composite. He states that it is important to realize that sociodemographic variables such as occupational status may convey different levels of meaning across cultural groups.

In one study, Laosa (1983) examined the influence that level of parental educational attainment had on how often the parents read to their children. Laosa based his selection of reading as a criterion on the premise that previous research indicates the amount of time parents invest reading to their child may positively affect their child's intellectual development.

Through home interviews with Hispanic and non-Hispanic White families whose children were in kindergarten, Laosa gathered data on how often both the mothers and fathers read to their children, and obtained sociodemographic information regarding their occupational status and level of attainment in 
school. Laosa determined that the parents who had attained a higher level of education read to their children more often than the parents with less education. The occupational status of the parents was not significantly related to how frequently they read to their children. This pattern remained the same for both ethnic groups. Laosa also compared how frequently the Hispanic and nonHispanic White parents read to their children, and discovered significant differences between the two ethnic groups. When the parents' occupational status was statistically held constant, he found that the non-Hispanic White parents read to their children more frequently than the Hispanic parents. However, when the parents' educational level was statistically held constant, the differences between the two ethnic groups disappeared. Laosa suggests that the "intellectual disadvantage observed among many ethnic minority children can be explained by the fact that ethnic minority parents on the average have attained fewer years of schooling than non minority parents" (p. 99). Laosa asserts that the ultimate amount of education a parent attains affects the continuity between home and school which a child experiences in regard to reading, a crucial element of the teaching and learning process.

Lareau's (1989) study comparing home-school relationships in two schools, one located in a working-class neighborhood, and 
the other in a middle class neighborhood, found that the differences in how parents respond to teacher requests and interactions with the school may explain the lower levels of achievement, and aspirations exhibited by the working-class children. Lareau asserts that class-related cultural factors influence parentteacher interaction.

The parents of children attending the middle-class school were primarily college-educated and employed in a variety of professions. Most parents of the children enrolled in the workingclass school were high school graduates, or had not completed high school, and were employed in skilled or semi-skilled occupations, or were receiving public assistance. Lareau conducted interviews with the parents, the teachers, principals and a resource specialist. She states that "...at both schools, the definition of the ideal family-school relationship was the same: a partnership in which family life and school life are integrated" (p. 76). In both schools, although the administrators and teachers thought of the parents as "partners" of the school, it was clear that parents were expected to defer to them. Teachers at the two schools did not vary in what they expected of the parents in terms of involvement and participation in their child's academic life.

Lareau found that parent response to teacher requests was much higher at the middle-class school than at the working-class 
school. Interactions between parents and teachers at the workingclass school were awkward and infrequent in comparison to the middle-class school. Lareau maintains that socioeconomic factors such as parents' educational level, their perception of the role of the teacher/school, and the time, money, and other resources (such as reliable transportation) available to them, influenced the amount of parent involvement at the two schools.

Lareau also noted that working-class parents expressed doubts about their own abilities to help their children due to their perceived or actual lack of education. Thus, these parents did not think they had a viable role as coeducators of their children, and they expected the school to be responsible for their child's academic progress. Lareau notes that “...middle and working-class parents' aspirations differed only in the level of achievement they hoped their children would attain" (p. 81). She asserts further that middle-class culture fosters connections between the school and the family, reinforcing teachers' positive attitudes toward their children, while working-class culture emphasizes separation between home and school. She states that this contributes to teachers' lower expectations for working-class children. Lareau asserts that if schools were to promote a different kind of homeschool partnership, middle-class culture might not provide such an advantage. Such changes in the way most traditional mainstream 
schools function would be sweeping. She states that schools “...play a crucial role in this process of social reproduction; they sort students into social categories that award credentials and opportunities for mobility" (p. 83).

Research indicates that there is a strong, positive correlation between socioeconomic factors and student achievement (Baker \& Stevenson, 1986; Lareau, 1989; Clark, 1983; Laosa, 1983). With each level of education their parents have completed, children's grades, test scores, and ultimate level of educational attainment tend to increase. However, the question of why this appears to be so remains. It is not a simple task to discover why and how SES impacts student achievement.

A study conducted by Eagle (1989) assesses the varying effects of SES, parental attention, mother's working patterns, and family structure on high school achievement. For her study, Eagle used a national data base consisting of information gathered on over 11,000 high school students. Achievement was defined in this study as enrollment in post secondary education, and attainment of a college degree. Family characteristics included in the SES composite were: family income, occupation of father, level of mother's and father's education, and number of certain major possessions, such as vehicles and appliances. Eagle found that “students' educational attainment was strongly associated with all 
five indicators in the SES composite" (p. 3).

Eagle also examined additional factors in the students' family background, including whether the student resided with one or both original parents (or neither original parent), parents' reading to the student in early childhood, parent involvement during high school, employment status of the mother, and availability of a specific place for study in the home. The family characteristics found to be most significantly related to achievement were parent involvement (described as frequency of talking with teachers, monitoring of schoolwork, and planning for post secondary activities) in high school, and parental reading. Eagle found that students from lower SES families tended to have parents who were less involved during high school, parents who read to them less in early childhood, and parents who did not have a specific place in the home set aside for doing homework.

To address whether high SES alone accounts for higher achievement, or whether family involvement in education has an independent effect, Eagle controlled for SES and discovered that three family background factors exhibited a significant impact independent of socioeconomic status. The most powerful of the three was parental involvement, followed by students living with neither original parent, and the number of possessions. While parents' educational level and SES appear to be consistently related 
to a child's educational achievement, Eagle concludes that "parents of any social class can contribute to their children's post secondary educational attainment by monitoring educational progress during high school" (p. 12).

It is critical for educators, administrators, and parents to realize that a child's academic success is not rigidly controlled by sociodemographic factors or cultural background. The parental support of learning at home has a profound, independent effect on achievement. Parents are in a much better position to assist their children in doing well when they are viewed by educators as partners in their children's academic journey, are kept informed by someone with whom they are comfortable about how their children are doing in school, and are given knowledge about the best ways to encourage their child's progress (Kellaghan, et al, 1993).

PARENTAL ATTITUDES AND BEHAVIORS AND RELATIONSHIP TO

\section{STUDENT ACHIEVEMENT}

Attitude has long been considered an important factor in second language acquisition and achievement (Spolsky,1969; Hermann, 1980; Gardner, 1968). Researchers postulate that parental attitudes are indicative of their children's attitudes and expectations (Epstein, 1987; Figueroa, 1993; Ravid, 1987). Studies in Canada have affirmed the influential role of parental 
attitude in the second language learning of children (Gardner, 1985; Goodz 1994). Berryman (1982) states, "I am convinced that the parent may be the key to the ultimate academic successes that minority group children experience" (p. 25). In research studies conducted with Hispanic families, Laosa (1983) asserts “parental behavior

will have important consequences for the child's development of specific cognitive skills, learning strategies, and personality characteristics" (p. 81).

Gardner and Lambert pioneered the modern era of research in the areas of attitude and motivation and their role in second language acquisition. Much of their research has focused on the French-speaking and English-speaking populations in Canada. Gardner (1968) introduced the concepts of integrative and instrumental motivation in second language learning. An individual is said to be integratively motivated when he/she desires to be identified with the target ethnolinguistic group, and is said to be instrumentally motivated to learn the second (or target) language if he/she desires to acquire it for the purposes of gaining employment/advancing a career, fulfilling an educational requirement, or improving one's social status (Gardner, 1968; Feenstra, 1969; Larsen-Freeman \& Long, 1991). With young children, the integrative motive, which in part includes one's 
attitude toward the target language community, is strongly influenced by the attitude of the parents toward that particular community (Gardner, 1968; Feenstra, 1969). Among the Hispanic immigrant community in the United States, many parents stress the instrumental motive for acquiring English. Many of these parents believe that their children should learn to speak English well in order to further their education, to secure stable employment, and to gain social acceptance in the dominant language society (Delgado-Gaitan, 1991; Torres, 1984). However, despite a significant body of research on the influence of parental attitudes on academic achievement among language majority (usually monolingual) children, direct research concerning the impact of this multi-faceted variable on English second language acquisition has been sparse. Yet, investigation of parental attitudes and actions in relation to the school performance of children continues to be of interest in the fields of education and ESL.

Recent research conducted by Okagaki, Frensch, and Gordon (1995) sought to identify parental beliefs and behaviors that are associated with school success among Mexican American children. Their study has provided the impetus for this investigator's exploration of parental actions and attitudes of language minority children.

The Okagaki, et al. study included thirty-three high-achieving 
and forty-nine low-achieving Mexican American fourth- and fifthgrade students and their parents. The students were assigned their respective designations based upon their scores on school achievement tests. The researchers chose to look at these extremes in student achievement because they were attempting to isolate "parental beliefs and practices that distinguish high achievers from low achievers" ( p. 163).

In order to assess the parents' beliefs and behaviors, Okagaki et.al. devised a questionnaire consisting of six sections. The parents responded to questions regarding educational expectations, educational values, parental efficacy, parents' perceptions of racial barriers, self-reported parental behaviors, and demographic information.

The researchers' data yielded some interesting results. The parents of both the high-achieving students and the low-achieving students expressed the same general value of the importance of education for their children. Parents were asked how much education they expected their child to receive; all responded that their children were expected to graduate from high school, and most (85\%) expected their child to graduate from college. Okagaki et. al. report that the responses for the two groups of parents did not differ in their distribution. However, the two groups differed in the minimum level of education they would permit their child to 
attain, before ceasing formal education. The parents of the higherachieving group set a higher minimum standard for their children.

In regard to parental perception of efficacy, the researchers concluded that nearly all parents thought they should assist their children with homework, and the majority of the parents believed they could be helpful. There was no difference in the amount of time the two groups of parents invested in helping their children. Okagaki provides some evidence that the parents of the high achievers were more confident that their assistance was effective. The self-reported parental behaviors included the frequency with which children were provided assistance on school work, how often parents engaged in various enrichment activities with their children, and how often literacy skills were modeled at home. The only difference reported by the two groups of parents was in regard to modeling of reading. In this case, the parents of the higherachieving students indicated reading in the home with greater frequency than the parents of the low achievers. Okagaki, et al. hypothesize that this behavior may convey to children that skills learned in school are valuable throughout life.

According to the researchers, parents may influence children's motivation for school success in several ways: by establishing high expectations for school performance, by stressing the value of knowledge gained in school and its relation to other 
areas of life, and by demonstrating the skills acquired in school.

\section{SUMMARY}

A review of the literature suggests support for the belief that parents have a substantial impact upon a child's academic performance. Whether specific parental attitudes and actions have an influence on a child's achievement in ESL deserves further inquiry. With funding for many ESL programs in jeopardy, it is important to increase parent and teacher awareness of the impact parent involvement has on the second language acquisition process of language minority schoolchildren. Quantifiable evidence regarding parental influence and its relationship to level of ESL proficiency is needed. If specific parental attitudes and behaviors can be linked with ESL achievement, educators and administrators may wish to promote these beliefs and behaviors among parents of language minority children. Such efforts on the part of administrators may in turn foster a stronger home-school connection, decrease the incidence of isolation of language minority students, and result in better communication among parents, the school system, and other members of the community. 
CHAPTER III

\section{RESEARCH METHODS}

This chapter outlines the research design for this study, including a thorough discussion of the subjects, the setting for each phase of the data collection, the testing conditions, and recruitment of parent and student participants. Detailed illustrations of each of the three instruments will be provided, as well as a description of reliability and validity measures for the LAS-O and the RMI. Also included in this chapter is a discussion of the data analysis, and a summary.

\section{SUBJECTS}

The subjects for this research are the students in a K-5 ESL program at a public elementary school in Oregon and their parents. The research site has a large number (approximately 100 for the 1995-1996 school year) of native Spanish-speaking children in the school population. The school enrolled one hundred thirty students in the ESL program for the 1995-96 academic year. The total school population is five hundred fifty students. The other language groups represented in the school are Russian, Vietnamese, 
Bosnian, and Japanese.

Approximately forty-five percent of the students at the research site school receive subsidized lunches. The socioeconomic level of the student body has been described by several of the teachers as lower middle class to middle class.

Figure 1. represents the educational level completed by the parents participating in this study. The majority of the parents have received the equivalent of an eighth grade education, or less. Figure 2. shows the length of parents' residence in the U.S., with seven and one-half years being the average period of residence. Types of parental employment are depicted in Figure 3.

Figure 1. Educational Level Completed By Parents

\section{Highest Level of Education Completed by Parents}

Grad. or prof. degree some grad. school Completed college Some college Some voc. training Completed h. s. Some h. s. Eighth grade Some grade school None

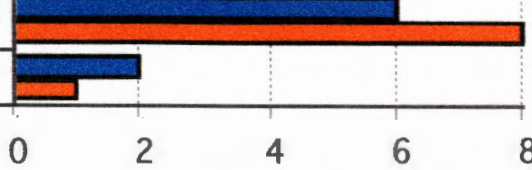
Level of Education Mother Level of Education Father 
Figure 2. Length of Parents' Residence in the U.S.

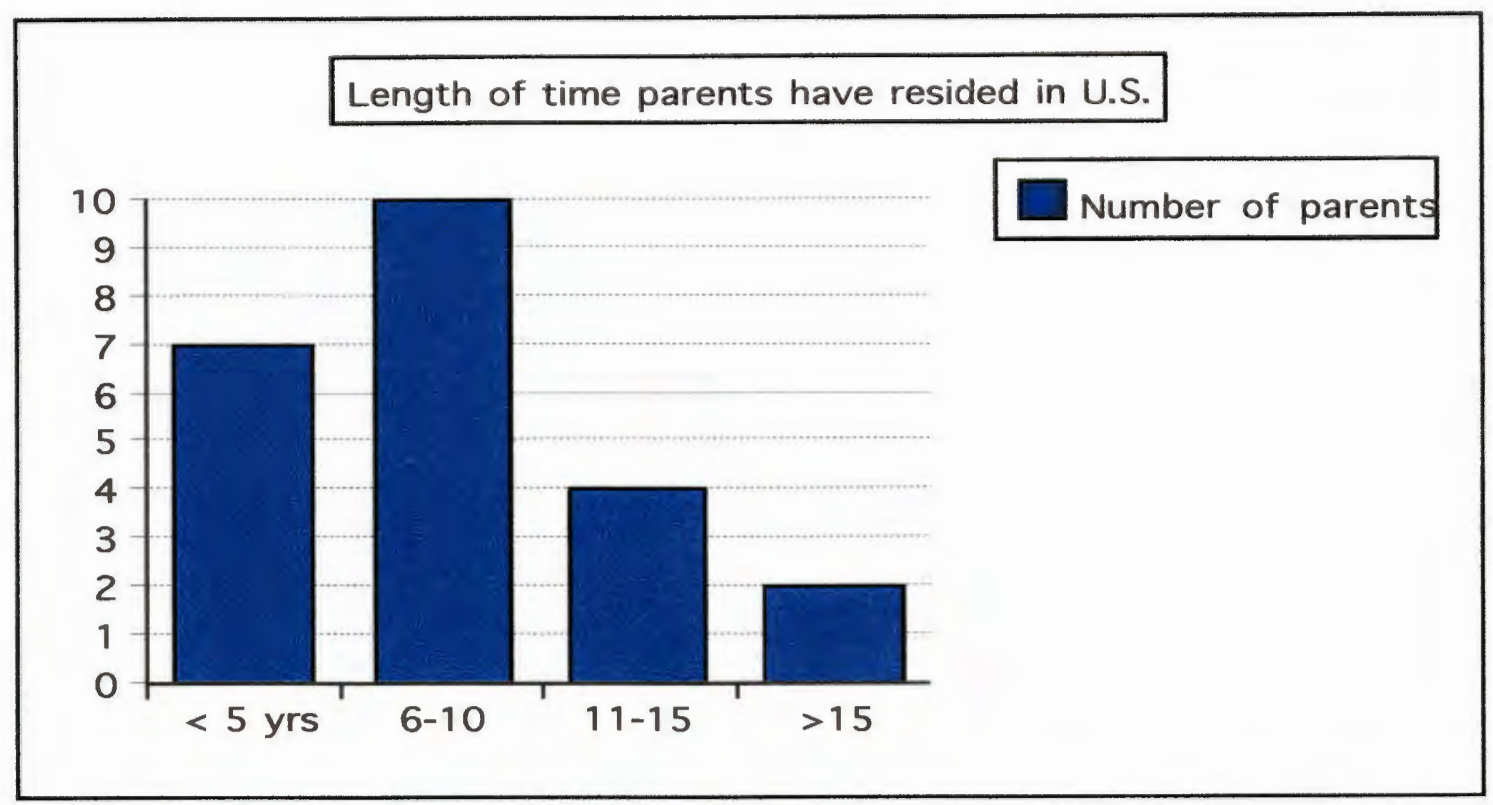

Figure 3. Types of Parental Employment

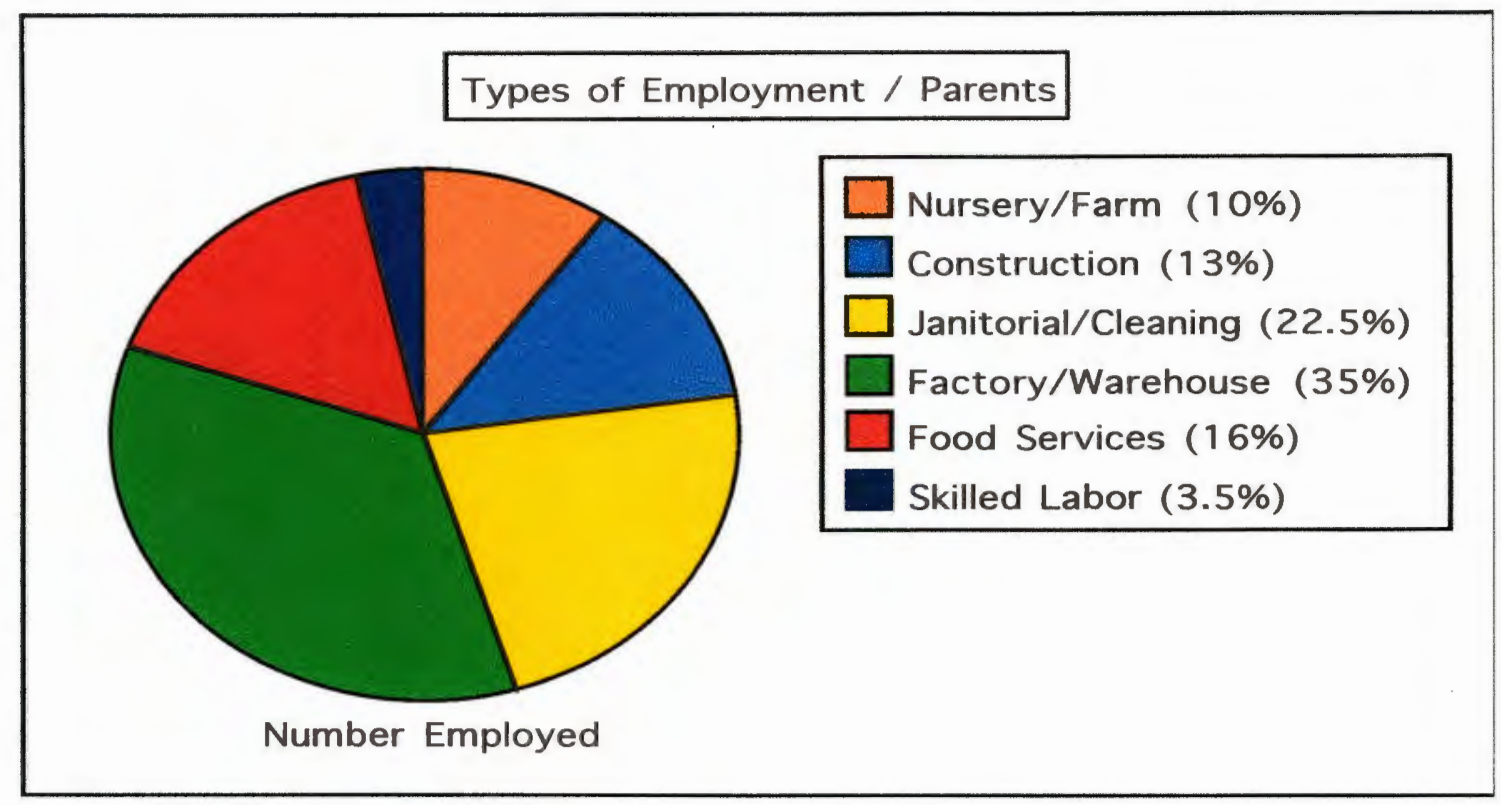


Ogbu (1991) describes two broad classifications of minority groups present in the United States. One group is termed an immigrant minority group and the other is described as an involuntary minority group. Members of an immigrant minority group are generally incorporated voluntarily into their respective societies. Some characteristics of immigrant minority groups are that they have moved to the present society in pursuit of greater religious or political freedom, economic opportunity, and enhanced opportunities for education and career advancement for themselves or their children. Involuntary minorities are defined by Ogbu as those individuals "who were brought into their present society through slavery, conquest, or colonization" (p. 9). Involuntary minorities generally perceive social, political, and economic barriers they encounter as undeserved oppression. According to Ogbu's definition, the parents and students participating in this research project are members of the immigrant minority group.

Permission to conduct the research at the public elementary school was granted after a series of lengthy meetings with the school principal, and conversations with representatives at the district headquarters. This research project was made possible in part by the full support of the ESL teacher and the migrant education coordinator. The principal set strict guidelines regarding contact with the students and the use of the school facilities for 
testing. Adherence with these guidelines did not hinder the researcher in the collection of the data.

In order to maximize participation for this research project, either parent was allowed to complete the questionnaire. Twentyseven parents completed the survey, representing forty children. Ultimately, twenty-three parents and thirty-six children were included in the study. Several children had to be disqualified because it was discovered that they were also part of the special education program, and were therefore untestable by this researcher because of their medical disabilities. Figure 4. represents the distribution of the student participants by grade level.

Figure 4. Distribution of Students By Grade Level

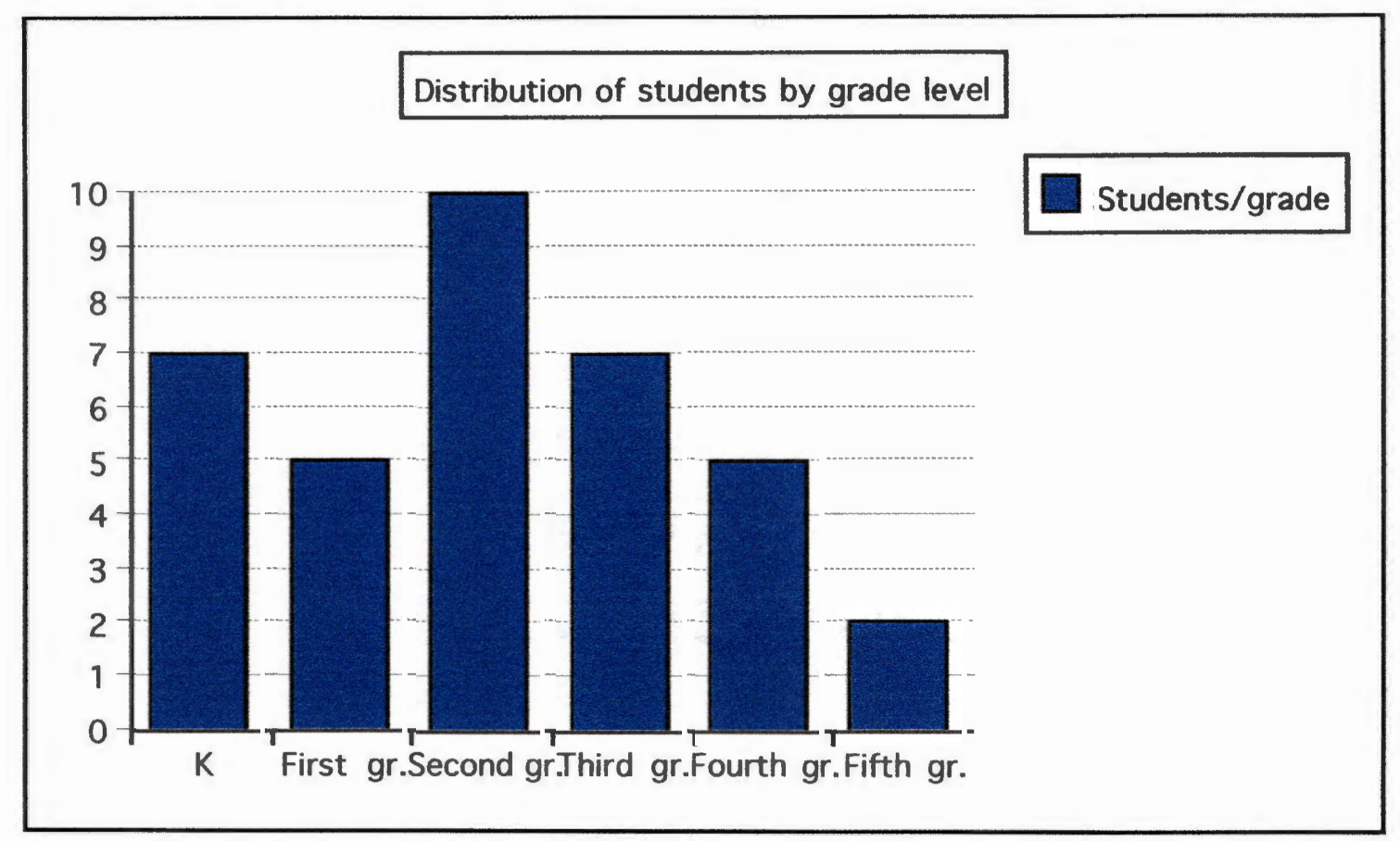


All of the participants in the study were assured on the consent form of the confidentiality of their responses. One consent form was used both for the parent questionnaire and for permission to administer the RMI and LAS-O tests and to collect the grade reports (see Appendix B). The consent form was read to the parents by the migrant education coordinator (a native speaker of Spanish) and time was allowed for inquiries regarding the consent form and the questionnaire. Neither parents nor students are named in this study. The school name and its location are not revealed, and all written material identifying the participants is stored in a locked filing cabinet.

\section{RESEARCH DESIGN}

The independent variables for this multivariate research design are: 1) parental attitudes and behaviors, 2) demographic factors, and 3) degree of parental efficacy. The dependent variables are: 1) the students' scores on the a) RMI and b) LAS-O tests, and 2) their first and second quarter grade reports and classroom evaluations.

The methodology employed to respond to the research questions included a questionnaire, which was completed by the parents of children in a kindergarten through fifth grade ESL program. Further details regarding the questionnaire will be 
discussed shortly. In his discussion of elicitation techniques, Nunan (1992) states that the questionnaire allows for the collection of data in a field setting, "....and the data themselves are more amenable to quantification than discursive data such as freeform field notes, participant observers' journals, the transcripts of oral language" (p. 143). Nunan mentions two possible threats to validity in using a questionnaire as an elicitation device. The researcher decides in advance which questions are to be explored, and in so doing, may omit other potentially important areas for investigation. Additionally, Nunan warns that the responses a researcher receives may be programmed by the very wording of the questions. Nunan suggests a pilot of any questionnaire.

This study adapted a questionnaire previously employed by Okagaki, et al. (1995). The instrument used by Okagaki, et al. included six sections: 1) educational expectations, 2) educational values, 3) parental efficacy, 4) parents' perceptions of racial barriers, 5) self-reported parental behaviors, and 6) demographic information. The section containing parents' perceptions of racial barriers was eliminated. Analysis and discussion of racial barriers encountered by minorities is not a variable in this research design, and is beyond the scope of this research project. A pilot study using the adapted instrument was conducted with a population of parents similar to the parents at the research site school. The 
eight pilot study participants were all native speakers of Spanish, had been in the United States for less than 5 years, and had children enrolled in elementary ESL programs.

The pilot study was invaluable for several reasons. First of all, it became apparent that the questionnaire was too long. Most of the participants needed at least 90 minutes to complete it, and required significant translation assistance to answer the questions. These participants, and the translator hired to assist the researcher, advised that some of the questions were awkward or contained words with uncommon translations. They made suggestions to change the vocabulary and syntax of some of the questions. The instrument was then revised substantially, and the number of questions in each category was reduced. After the pilot questionnaire was revised, it was reviewed by the migrant education coordinator and one of the ESL teachers at the research site school, to ensure that the final version of the questionnaire would be in an acceptable format for the study participants. A few minor translation changes were made at that time. Marin and Marin (1991) stress the importance of consideration of the participants' cultural background when devising a questionnaire. Although the parents involved in this research project were not completely unfamiliar with forms and questionnaires, great care was taken in this instance to devise an instrument that would not be 
intimidating, and one that would be fairly easy to read in terms of vocabulary and format.

\section{DATA COLLECTION PROCEDURES}

The collection of the data for this research project occurred over several months during the 1995-1996 academic year. In discussing research with Hispanic populations, Marin and Marin (1991) advise that for successful data collection to occur, it is imperative that the researcher involve a respected and known community member to assist with participation for the project. In this instance, the migrant education coordinator is a very wellknown and respected member of the community. In addition to her formal role with the school district, she serves as the informal counselor, social worker, mediator, and parent to many of the immigrant families.

The school secretary and the migrant education coordinator at the research site school supplied the names, addresses, and phone numbers of all the parents of children in the ESL program. The investigator set up a meeting at the school for the parents to attend, with the purpose of completing the parent questionnaire. A flyer was composed describing this event, which was then translated and mailed on colorful paper to each of the families (see Appendix A). In addition, each family was telephoned the week of 
the meeting to encourage attendance. In order to ensure adequate participation, and as a way of thanking the parents for their help with this research project, the researcher also arranged for two speakers to come to the meeting. One native Spanish speaker came from the Internal Revenue Service to help the participants with tax forms, and an admissions counselor from Portland State University came to talk with the parents about college opportunities for minority language students. Five high school students attended this portion of the meeting. The parents were especially grateful to obtain college information from a native of Mexico, who had a successful postsecondary education experience in her second language.

In addition, the parents were advised that if they came to the meeting and completed the survey, they would receive a new book in Spanish for their child. Refreshments were provided for the forty parents and twenty-three children who attended. Four translators were available to assist the parents with the questionnaire. This meeting was held in the school library, which is where other meetings for parents of the children in the ESL program are held. The parents sat at tables to complete the questionnaire. Pencils with erasers were provided to each participant.

The consent forms (see Appendix B) which the parents signed 
permitting the participation of their child/children in the study were matched with the class student lists. Thirty-six children participated in this research project. The researcher met with each of the eight teachers for these students and explained the proposed research and testing. Arrangements were then made to remove the students from their classes for the testing when it was least disruptive to both student and teacher. The administration of the Language Assessment Scale--Oral Proficiency (LAS-O) and Reading Miscue Inventory (RMI) tests occurred over a two month period.

The LAS-O and RMI tests were done with each student individually. Testing times were coordinated with each mainstream classroom teacher, and no students missed a crucial portion of their class time. Some students chose to miss recess or an elective such as art, physical education, or music. Many students chose to perform the tests during their library segment. A small, quiet room at the school was reserved for the testing. This was the same room that is reserved for ESL testing and placement, as well as for testing for the talented and gifted program; thus all of the students were familiar with the setting. This windowless room was equipped with one large table and chairs, and a tape recorder. The LAS-O required ten-fifteen minutes of the student's time, and the RMI required approximately 
thirty minutes to complete.

\section{INSTRUMENTS AND MATERIALS}

Students' achievement in English reading and oral proficiency was evaluated by their results on two tests, the RMI, (Reading Miscue Inventory) and the LAS-O (Language Assessment Scale of Oral proficiency) administered by the researcher. First and second quarter grade reports for mainstream classes were also collected for analysis. To ensure the reliability of the scoring for these two tests, an experienced ESL educator reviewed the data collected by the researcher. The parent questionnaire, adapted from an instrument used by Lynn Okagaki (Okagaki, et al., 1995) in a study of school achievement in Mexican American children, was translated into Spanish, and then back translated into English by two different translators. The translations are identical. The English version of the questionnaire is contained in Appendix C, and the Spanish version is found in Appendix D.

THE QUESTIONNAIRE

The questionnaire, or parent survey, was composed of twenty-four questions designed to address the variables of parental educational expectations and values, parental behaviors, and parental perception of efficacy. An additional 12 questions 
were demographic in nature. All of the participants completed the survey within thirty minutes, and the majority completed it within twenty minutes.

\section{THE LANGUAGE ASSESSMENT SCALE OF ORAL PROFICIENCY (LAS-O)}

The Language Assessment Scale of Oral Proficiency (LAS-O), developed by De Avila and Duncan (1990), measures vocabulary comprehension, production, aural discrimination and pronunciation. The LAS-O does not measure achievement in course content, although it does measure oral English language skills necessary for functioning in a mainstream class environment. The LAS-O is composed of oral language and pronunciation components. The LAS0 is designed to assess students in grades 1-6, and the Pre-LAS is designed to assess students in the kindergarten level. The authors indicate that the Pre-LAS may also be appropriate for very lowlevel first-graders, although the school district in which the research site school is located administers the Pre-LAS only to kindergartners. For this research project, the LAS-O was administered to the children in grades 1-5, and the Pre-LAS was given to the kindergartners.

De Avila and Duncan indicate that the LAS-O employs a convergent approach to assessment of oral proficiency: the total oral score is based on performance across the linguistic 
subsystems and utilizes diverse measurement procedures, content areas, and scoring procedures....we have attempted to incorporate into the assessment procedures the idea of 'language in context' (1990, p. 2).

The LAS-O test itself consists of a cassette tape and a

picture book. The students are first shown the picture book, and are asked to identify (orally) the items to which the test administrator points. These scenes include pictures of a playground/schoolyard, a classroom, a home, and a kitchen. The students are then asked to listen to a cassette tape of a very short story/conversation. At the conclusion of the story, the students are asked to answer yes/no questions about the conversation by the same narrator of the story. The most challenging portion of the LAS-O for many of the students is the Story Retelling, in which the children listen to a story on the cassette, follow along with the pictures corresponding to the story, and after they have finished listening to the story, retell it to the test administrator in their own words. The test administrator writes down the student's version verbatim, and scores it after the student leaves the room.

Parts 1 and 2 of the oral language section, and parts 4 and 5 of the pronunciation section of the LAS-O are scored simultaneously with administration. The raw scores (number correct) for these four sections are entered directly on the LAS-O test form. Part 3 of the test, the Story Retelling, is scored after 
the student leaves the testing site. The LAS-O Scoring and Interpretation manual provides instruction for scoring the Story Retelling section of the test. To help ensure reliability and validity for the scoring for this section of the test, an experienced ESL educator separately tabulated the Story Retelling section. Agreement in scoring between the researcher and the ESL educator was found in $90 \%$ of the scores, which is an acceptable percentage for inter-rater reliability, according to De Avila and Duncan (1990).

\section{THE READING MISCUE INVENTORY (RMI)}

The Reading Miscue Inventory (RMI) serves a variety of purposes for a number of different people, including researchers, curriculum developers, teachers, reading specialists, and special educators (Goodman, et. al., 1987). The RMI allows teachers to gain insight into the reading process. The research site school uses the RMI to assess the reading proficiency in English of students upon entrance to and exit from the ESL program. This information is then considered along with other test data for purposes of placement of language minority children in the district. The primary purpose of miscue analysis is to analyze the oral reading of individual students. Each miscue analysis procedure can assist the teacher in determining the quality and variety of a student's miscues through the questions following the narration of the text. 
The data obtained from the RMI can assist teachers in planning specific reading instruction, and can help to pinpoint problem areas or gaps in learning. It is important to note that the miscue analysis can provide evidence of the reader's strengths, as well as to highlight weaknesses.

The testing for the RMI occurred in the same setting as the LAS-O. The format for administration of the RMI is as follows: The student is tested individually, and the appropriate test material is assigned by grade level. A sample RMI is included in Appendix E. Each grade level (1-5) contains a short story in book format for the child to read aloud to the test administrator. The story has not been previously practiced or read by the student. As the child reads, the administrator follows along with a separate text and marks the miscues made by the student. The administrator is not allowed to offer any assistance to the student while he/she is reading. After the student concludes reading the story, the test administrator asks the student a series of questions, which are included with each story. The student is asked to retell the story as if the researcher has never heard it. As the student does so, the researcher marks off items included on the test sheet. Categories include the characters in the story, events in the story, setting, plot, and theme. Each item/word in each category has a designated point value. The student's score is tallied after he/she leaves the 
testing site. This number score is the indicator of the student's reading comprehension of that particular story. Because miscue analysis examines the way in which the reader's language, thought, and experiences function in reading, the miscues recorded by the teacher can help to "determine the varying causes of miscues, pinpoint specific and repetitive problems, and distinguish these problems from difficulties caused by the syntactic complexity or conceptual load of the reading material" (Goodman, et. al. 1987). For the purposes of this research project, only the reading comprehension score was included in the data analysis.

\section{DATA ANALYSIS}

In order to obtain sufficient numbers within each cell, Okagaki, et al. (1995) collapsed across the three disagree ratings and the three agree ratings, which corresponds to numbers $16-24$ on the questionnaire used for this research project. Okagaki, et al. (1995) used a chi-square analysis on their data collected from the eighty-two participants. A chi-square analysis was not effective for this research project because the expected value in each cell did not exceed 5; therefore Fisher's Exact Test (also known as Fisher's Test) was employed to analyze the data. Fisher's Test and $2 \times 2$ contingency tables allow the researcher to calculate whether observed frequencies are due to chance alone or represent 
significant relationships. It can be used when the size of the test group is small. This test also analyzes data where there is uneven distribution in the responses, and no method to predict what an average response would be (Phillips, 1978). The complete Fisher's Test formula is reproduced in the following chapter, along with an example of how this test was used with the data. Questions 4-13 addressed self-reported parental behaviors, and were answered on a six-point Likert-type scale. Again, the data were collapsed across the two general ratings categories of "about once a week or more" and "about once a month or less" in the same manner in which Okagaki, et. al. analyzed their data. Questions 1-3, 14, and 15 were also answered on a Likert-type scale, ranging from 4-7 points. The data from questions 1 and 2 regarding parental educational expectations and values were collapsed into two categories: "graduate from high school" and "graduate from college." Question 3, which addressed parental perception of efficacy, was collapsed into "generally confident" and "less confident." Questions 14 and 15 were evaluated in the same manner. The demographic information was analyzed descriptively, and the results are contained in the tables in this chapter and in Chapter IV.

Although the children's first and second quarter grade reports were collected, multiple regression analysis proved to be futile. 
Teachers assigned one of three grades when evaluating students.

Nearly all of the children received a grade of 2 (which means "making steady progress") on their first and second quarter transcripts. In other words, there was almost no variation to be found in the children's grade reports, making statistical analysis impossible. Perhaps one explanation for the grades assigned to these children comes from the researcher's classroom observation. All of the teachers at the research site school are fluent in Spanish. Very often when a student did not appear to understand the instructions or the lesson in English, the teacher offered assistance in Spanish. It is difficult to determine how accurately the grades reflect the students' grasp of English in this setting. However, the RMI and LAS-O data show variation from student to student, and may be much more accurate indicators of the students' level of English second language acquisition.

\section{SUMMARY}

A study of this nature does have some limitations. The size of the sample is small; thus some differences that are seen may not actually attain statistical significance, but might in a larger sample size. As with any self-report data, accuracy of the parent responses may be a problem. The parent participants in the Okagaki, et. al. study were primarily second generation Mexican 
American, whereas the twenty-three parent participants for this research project were primarily Mexican immigrants (two parents immigrated from Guatemala). However, despite the small sample size, there appears to be some positive predictive value seen in the data, similar to that observed by Okagaki, et al. This will be discussed in detail in the following chapters. 


\section{CHAPTER IV \\ RESULTS AND DISCUSSION}

This chapter presents the results of the data analysis, and includes graphs, tables, and an example of how the Fisher Test formula was used to analyze the data. The findings will be presented for each of the variables discussed in the previous chapter: parental educational expectations and values, parental perception of efficacy, self-reported parental behaviors, and demographic factors.

A portion of the raw data collected by the researcher is reproduced in this chapter to facilitate discussion of the data analysis. On the parent questionnaire (see Appendix $\mathrm{C}$ ), respondents had the option of choosing from an array of possible answers for each question. Table 1 shows the number of parents who responded with a particular answer for questions 1-24. Six of the twentythree parent participants were fathers of the children in the study, and seventeen were mothers. The demographic data (questions 2537) are not included in this table, as most of that information is found in other graphs or tables in this thesis, or is represented descriptively. Table 2 represents the students' RMI and LAS-O 
results, and Tables 3 and 4 interpret these scores.

\section{Table 1}

\section{Summary of Parent Questionnaire Responses}

Key: questions $1,2=$ options $1-7$

question $3,14,15=$ options $1-4$

questions $4-13,16-24=$ options $1-6$

Parent Responses (Options 1-7)

\begin{tabular}{|c|c|c|c|c|c|c|c|c|}
\hline & 1 & 2 & 3 & 4 & 5 & 6 & 7 & Total Responses \\
\hline \multicolumn{9}{|c|}{ Question } \\
\hline 1 & & & & & & 7 & 16 & 23 \\
\hline 2 & 1 & & & & & 8 & 13 & 22 \\
\hline 3 & 14 & 3 & 2 & 3 & & & & 22 \\
\hline 4 & 3 & 1 & 2 & 11 & 2 & 5 & & 23 \\
\hline 5 & 3 & 4 & 2 & 1 & 5 & 7 & & 22 \\
\hline 6 & & 1 & 1 & 1 & 3 & 15 & & 21 \\
\hline 7 & & & 1 & & 3 & 19 & & 23 \\
\hline 8 & 2 & 1 & 3 & 5 & 4 & 8 & & 23 \\
\hline 9 & & & 3 & 4 & 7 & 9 & & 23 \\
\hline 10 & 5 & 4 & 3 & 4 & 1 & 4 & & 21 \\
\hline 11 & 7 & 4 & 3 & 2 & 1 & 4 & & 21 \\
\hline 12 & 12 & 4 & 1 & 1 & 1 & 3 & & 22 \\
\hline 13 & & & & 1 & 1 & 21 & & 23 \\
\hline 14 & 8 & 2 & 8 & 1 & & & & 19 \\
\hline 15 & & 6 & 11 & & & & & 17 \\
\hline 16 & & 2 & & & 2 & 17 & & 21 \\
\hline 17 & 2 & & 3 & & 3 & 14 & & 22 \\
\hline 18 & 15 & 5 & 1 & & & 2 & & 23 \\
\hline 19 & 8 & 4 & 1 & 1 & & 9 & & 23 \\
\hline 20 & 13 & 4 & 1 & & & 1 & & 19 \\
\hline 21 & 2 & & 1 & & & 20 & & 23 \\
\hline 22 & & & & & 2 & 21 & & 23 \\
\hline 23 & 18 & & & & 1 & 4 & & 23 \\
\hline 24 & & & & & & 22 & & 22 \\
\hline
\end{tabular}


Table 2

\section{RMI and LAS-O Data Table}

\begin{tabular}{|c|c|c|c|}
\hline Student & $\begin{array}{c}\text { Student Grade } \\
\text { Level }\end{array}$ & $\begin{array}{c}\text { RMI Score } \\
\text { /Level }\end{array}$ & $\begin{array}{l}\text { LAS-O Score } \\
\text { /Level }\end{array}$ \\
\hline 1 & 3 & $100 / 5$ & $100 / 5$ \\
\hline 2 & K & $0 / 1$ & $86 / 4$ \\
\hline 3 & 3 & $68 / 3$ & $70 / 3$ \\
\hline 4 & 2 & $0 / 1$ & $72.5 / 3$ \\
\hline 5 & K & $0 / 1$ & $49.5 / 1$ \\
\hline 6 & 3 & $80 / 4$ & $96.5 / 5$ \\
\hline 7 & 1 & $0 / 1$ & $77.5 / 4$ \\
\hline 8 & 2 & $81 / 4$ & $71.2 / 3$ \\
\hline 9 & K & $0 / 1$ & $76 / 3$ \\
\hline 10 & 2 & $28 / 1$ & $15 / 1$ \\
\hline 11 & 3 & $22 / 1$ & $26.2 / 1$ \\
\hline 12 & 2 & $83 / 4$ & $76.3 / 4$ \\
\hline 13 & K & $0 / 1$ & $73.5 / 3$ \\
\hline 14 & K & $0 / 1$ & $66 / 2$ \\
\hline 15 & 3 & $0 / 1$ & $78.8 / 4$ \\
\hline 16 & 5 & $81 / 4$ & $90 / 5$ \\
\hline 17 & K & $0 / 1$ & $86 / 4$ \\
\hline 18 & 4 & $86 / 5$ & $96.3 / 5$ \\
\hline 19 & 4 & $64 / 2$ & $86.3 / 5$ \\
\hline 20 & 2 & $0 / 1$ & $83.7 / 4$ \\
\hline 21 & 3 & $94 / 5$ & $75 / 4$ \\
\hline 22 & 4 & $77 / 4$ & $97.5 / 5$ \\
\hline 23 & K & $0 / 1$ & $63 / 2$ \\
\hline 24 & 4 & $37 / 1$ & $71.2 / 3$ \\
\hline 25 & 2 & $73 / 3$ & $81.3 / 4$ \\
\hline 26 & 5 & $16 / 1$ & $90 / 5$ \\
\hline 27 & 2 & $87 / 4$ & $88.5 / 5$ \\
\hline 28 & 2 & $85 / 4$ & $75 / 4$ \\
\hline 29 & 1 & $0 / 1$ & $48.8 / 1$ \\
\hline 30 & 3 & $87 / 4$ & $80 / 4$ \\
\hline 31 & 1 & $0 / 1$ & $15 / 1$ \\
\hline 32 & 2 & $0 / 1$ & $82.5 / 4$ \\
\hline 33 & 1 & $0 / 1$ & $71.3 / 3$ \\
\hline 34 & 2 & $0 / 1$ & $25 / 1$ \\
\hline 35 & 4 & $55 / 2$ & $72.5 / 3$ \\
\hline 36 & 1 & 1 & $70 / 3$ \\
\hline
\end{tabular}


Table 3

Interpretation of Scores for LAS-O

LAS-O

Total Score

85-100

75-84

$65-74$

55-64

$0-54$

1

Level

5

4

3

2

1

Category

Fluent English

Speaker $(F)$

Limited English

Speaker (L)

Non-English

Speaker $(N)$

Table 4

Interpretation of Scores for RMI

\section{$\underline{\mathrm{RMI}}$}

Total Score

90-100

80-89

$70-79$

60-69

$0-59$
Level

5

4

3

2

1

\section{Category}

Fluent English

Proficiency ( $F$ )

Limited English

Proficiency (L)

Non-English

Proficiency (N)

As can be seen from Table 2, eleven (approximately thirty percent) of the 36 children tested as fluent English readers. Twenty-two children (sixty-one percent) tested as non-English 
readers. Although reading is not taught until the first grade, all of the children were administered the RMI, in order to provide each student with the opportunity to demonstrate his/her reading skill. The high number of children who are not proficient readers in English reflects the representation of seven kindergartners and five first graders among the study participants. For purposes of the data analysis, the scores of the kindergarten students were eliminated, because none of them had been taught to read, and all scored zero. Three second grade students and one third grade student reported to the investigator that although they could not read in English, they read Spanish books at home or during free reading time in class. Three of these same children tested as fluent English speakers on the LAS-O (level 4), and the fourth child tested as a high level 3 student on the LAS-O.

Nineteen students (fifty-three percent) tested as fluent English speakers. Eleven students (approximately thirty percent) tested as limited English speakers, and six students (sixteen percent) tested as non-English speakers. Interestingly, three of the students who tested as fluent English speakers were in kindergarten or first grade. Oral second language proficiency in younger schoolchildren is frequently attributed to the assistance of their older siblings with schoolwork. Additionally, many older siblings speak to the younger children in the family in the second 
language (Wong Fillmore, 1990; Caplan, et al., 1992), yet two of these three young students did not have any older siblings. There may be other factors, such as IQ, parental behaviors not assessed or reported on the questionnaire, or other unknown variables influencing the oral proficiency of these students.

\section{PARENTAL EDUCATIONAL EXPECTATIONS AND VALUES}

All of the parents participating in this research project reported holding a very high value for education. Regarding educational attainment, twenty-two of the twenty-three parents indicated that they will not let their child stop going to school until he/she completes college (question 2). Additionally, all of the parents expected their children to complete college (question 1). Eighty-seven percent of the parents agreed with the statement that "a good education is the best way to get a good job" (question 21). All of the parents agreed with the statement "to have a good education is more important than to have a lot of money" (question 22).

Ninety-five percent of the parents disagreed with the statement "if my child works hard, he/she will not need a high school diploma to get a good job" (question 20). All of the parents expect their children to possess a strong work ethic, indicated by their agreement with the statement "I expect my child to work as 
hard as he/she can to get good grades in school" (question 24). It is apparent that the participants in this research project want their children to obtain a good education. These results are consistent with the findings of other researchers that ethnic minority/language minority parents place a high value on education (Clark, 1993; Goldenberg, 1987; Okagaki, et al., 1995).

\section{PARENTAL PERCEPTION OF EFFICACY}

For parental perception of efficacy, parents responded to the question "if your child has a problem or question about his/her homework, do you feel that you (or your spouse) can help your child?" Fifty-three percent of the parents reported that they feel generally confident in their ability to help their child with homework. Forty-seven percent of the parents reported that they feel less confident in their ability to assist their child with schoolwork. If parents responded that they feel generally confident in their ability to assist their child with schoolwork (score 1-2), their children were more likely to score 80 or greater on the RMI $(p=0.0376)$. The children of these parents also scored higher on the LAS-O $(p=0.0734)$. The data for parental perception of efficacy appear in Table 5. 
Table 5

Fisher's Test and Data Analysis

\begin{tabular}{|l|c|c|c|}
\multicolumn{1}{c}{ RMI $\geq 80$} & $\mathrm{RMI} \leq 79$ & Row Total \\
\hline $\begin{array}{l}\text { Generally } \\
\text { Confident } \\
\text { (score 1-2) }\end{array}$ & 6 & 4 & 10 \\
\hline $\begin{array}{l}\text { Less } \\
\text { (score 3-4) }\end{array}$ & 3 & 13 & 16 \\
\hline
\end{tabular}

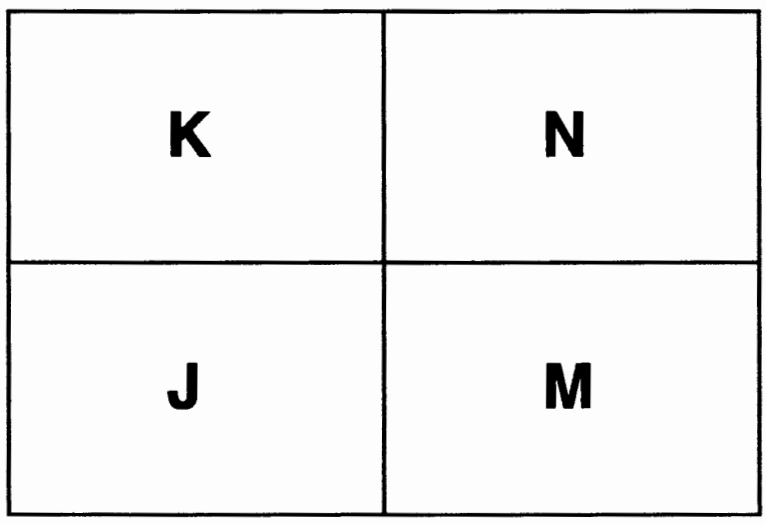

Fisher's Test (Fogiel, 1996)

$$
\begin{aligned}
& P=\frac{(J+K) !(N+M-J-K) ! N ! M !}{K ! J !(N-K) !(M-J) !(N+M) !} \\
& P=\frac{(3+6) !(10+16-3-6) ! 10 ! 16 !}{6 ! 3 !(10-6) !(16-3) !(10+16) !} \\
& P=\frac{9 ! 17 ! 10 ! 16 !}{6 ! 3 ! 4 ! 13 ! 26 !} \\
& P=0.0376
\end{aligned}
$$


PARENTAL BEHAVIORS

The parents responded to several inquiries regarding certain behaviors, or actions, within the home environment. Nineteen of the twenty-three parents revealed that they assisted their children with homework three days or more in the week prior to answering the questionnaire (see Figure 5).

Figure 5. Number of Days Per Week Parent Helped Child with Homework

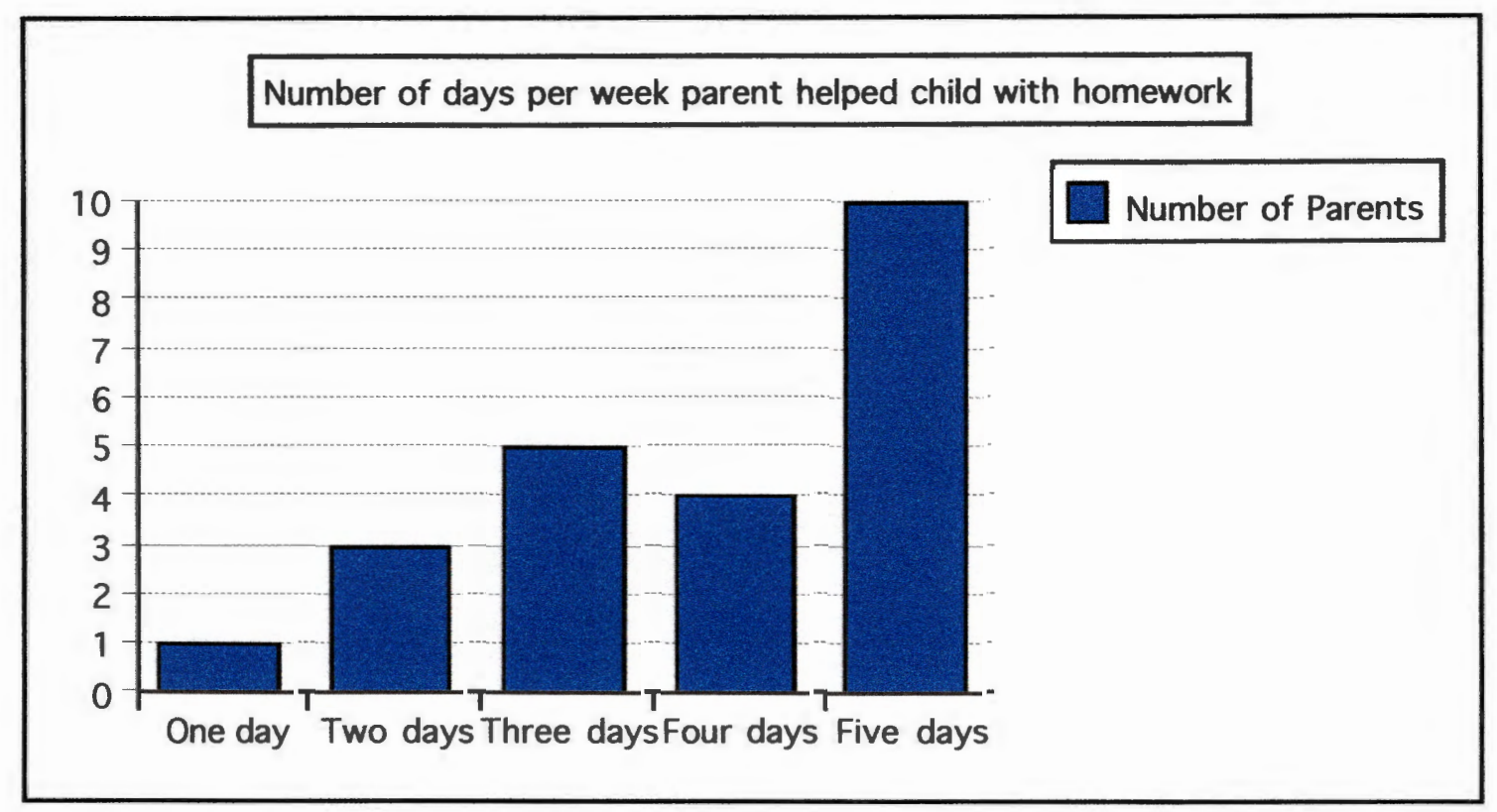

Based upon a review of the literature and parental behaviors previous researchers have found relevant, several survey questions were designed to assess the impact of parental modeling of reading on child ESL proficiency. Fifty-six percent of the parents 
responded that they read a newspaper or magazine "about once a week or more" (question 10, score 4-6 on the parent survey). Their children were more likely to score greater than or equal to 80 on the $\operatorname{RMI}(p=0.0823)$. However, a similar trend was not observed in the children's scores on the LAS-O for this question $(p=0.1992)$.

Fifty-seven percent of the parents who claimed that they read a book themselves "about once a week or more" (question 11) had children who scored greater than or equal to 80 on the RMI ( $p=$ 0.1158 ), opposed to twenty-five percent of the parents who read a book "about once a month or less." On the LAS-O portion of this question, the $p$ value $=0.2934$. When parents were asked how often they "get a library book or buy a book to read" (question 4), seventeen responded "about once a week or more" and six responded "about once a month or less." Again, the results for both the RMI and LAS-O were not significant for this question ( $p=$ 0.1304 , and $p=0.1219$, respectively). Question 5 addressed how often parents have a child read a non-school book at home. There were no significant differences noted for this question (RMI $p=$ 0.2945 and LAS-O $p=0.2662$ ).

Ninety percent of the parents reported reminding their child/children to study several times each week, and all of the parents reported that they asked their child/children how he/she was doing in school more than once a week. 


\section{DEMOGRAPHIC FACTORS}

The parents and children who participated in this research project share many similarities in their home environments. Only one household does not own a television. Seventy-four percent of the parents reported that their children watch T.V. in both Spanish and English, seventeen percent of the parents indicated that their children watch T.V. in English and not in Spanish, and one family reported that their children only view Spanish television programs. In regard to the language spoken by family members in the home, twenty-two parents reported that Spanish is spoken exclusively, and one parent responded that both English and Spanish are spoken in the home.

Question 35 asks the parents to indicate with whom the child lives most of the time. Nearly seventy percent (25 of the 36 children) live with two biological parents. The high percentage of intact nuclear families in this study may be a reflection of the Hispanic core value of familialism, which encompasses "...strong identification with and attachment to ...nuclear and extended families, and strong feelings of loyalty, reciprocity, and solidarity among members of the same family" (Marin \& Marin, p. 13). The parents' responses to question 35 are shown in Figure 6. 
Figure 6. Residence of Child

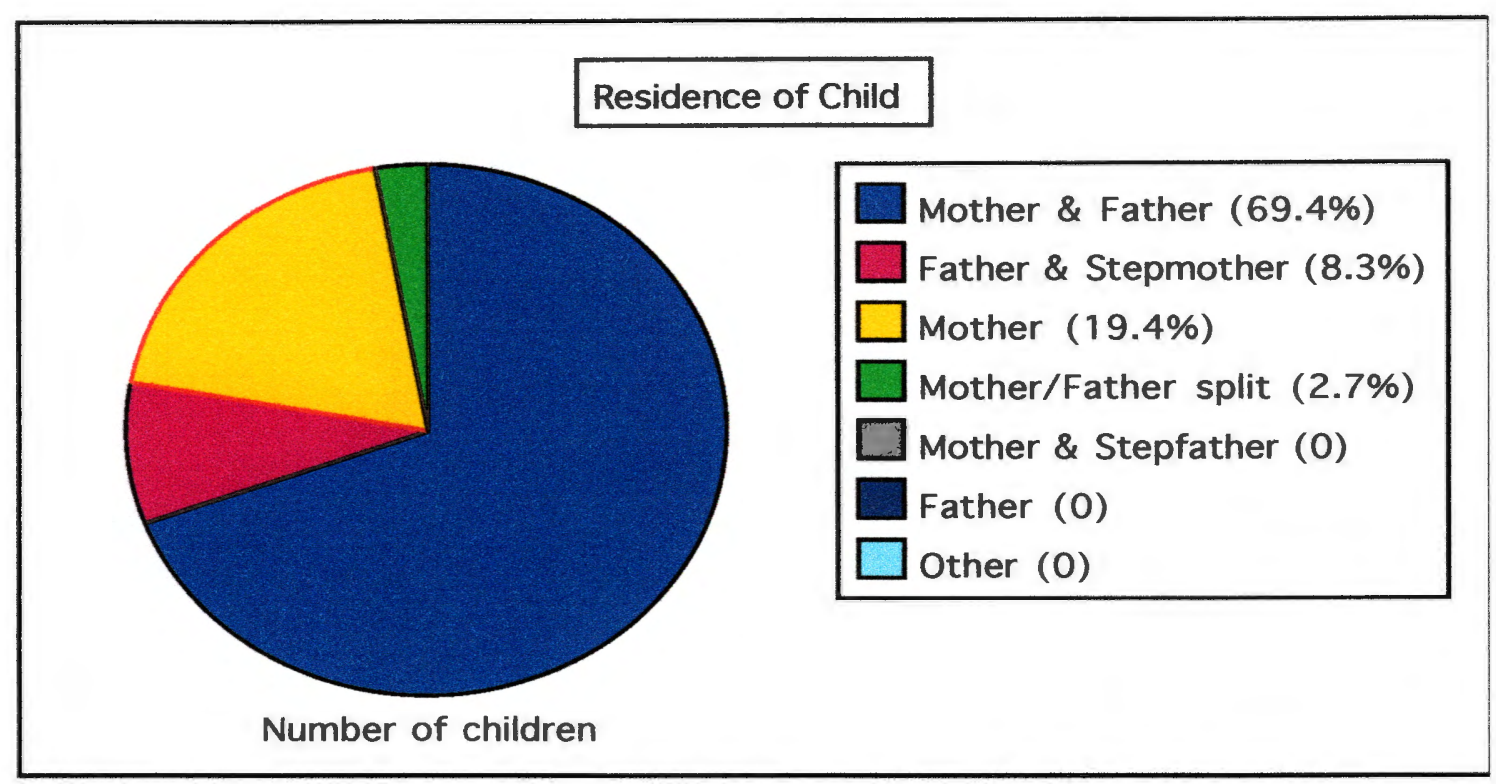

As mentioned in chapter 3 , the majority of the parents have received the equivalent of an eighth grade education or less (see Figure 1). Most are employed in jobs involving physical labor. However, despite the parents' modest level of educational attainment and employment in low-prestige jobs, their educational and career expectations for their children are high.

\section{PARENTAL VALUES}

Question 8 asked parents to respond how often they "talk about values or religious beliefs" with their child. Interestingly, parents who reported that they were less likely to discuss their values and religious beliefs had children who scored higher on the 
LAS-O $(p=0.0214)$. The results for the RMI on the same question were not statistically significant $(p=0.1896)$. In an attempt to explain this result, the hypothesis was made that length of residence in the U.S. after immigration contributes to declining discussion of religious values. However, further scrutiny does not support this hypothesis. The mean length of residence for the parents reporting less discussion of values/religious beliefs was nine and one-third years, and for the remaining parents the mean length of residence was seven years.

Ninety-five percent of the parents agreed with the statement "my child will do well if he/she learns to be independent, to do things on his/her own" (question 16), and seventy-eight percent of the parents disagreed with the statement "parents don't need to know where their child is if the child is playing with friends" (question 23). Okagaki, et. al (1995) and Okagaki and Sternberg (1993) collected data indicating the opposite results on the above two survey items. The fact that the parents participating in this research project were immigrants, and the participants in the other studies were first- or second-generation Mexican American may account for the differing parent responses. Additionally, the average age of students in this study was slightly younger than that of the students in Okagaki's studies, which may be a factor in the parent responses regarding a child's level of independence and 
autonomy.

\section{SUMMARY}

This study is an attempt to identify some underlying factors that may be related to a child's achievement in ESL. The generalizability of the findings is limited by the small sample size, and by reliance upon self-reported parental behaviors. However, some of the findings are consistent with those of Okagaki, et. al. (1995), after whose study the present one was modeled.

These data indicate that language minority parents value education highly, expect their children to be diligent with their schoolwork, and that hard work in the absence of a high school diploma does not indicate success. These findings support those of Okagaki, et al. (1995). Parental perception of efficacy appears to be an important element in a child's English reading proficiency. As Okagaki, et al. found in their study, parents of low achievers in this research project also reported assisting their children with homework just as often as did the parents of the higher achievers, but the parents of the children scoring higher on the RMI seemed more convinced that their assistance was effective. Additionally, the children of parents who read a magazine or newspaper with some frequency tend to score higher on reading proficiency.

Further discussion of the results of the data analysis will occur in the following chapter, and will include recommendations 
for future research, strengths and limitations of this study, and implications for teachers and administrators. 


\section{CHAPTER V}

ANALYSIS, CONCLUSIONS, AND IMPLICATIONS

The purpose of this study was two-fold: to provide

documentation regarding the influence of parental attitudes and behaviors on child ESL acquisition, and to provide teachers and administrators with an awareness of which parental attitudes and behaviors appear to have a positive impact on the second language learning process, so that these identified parental beliefs and actions might be promoted and encouraged.

A questionnaire was employed to collect data from the parents of students who were enrolled in a public elementary ESL program during the 1995-1996 academic year. Two measures of proficiency were administered by the researcher to the student participants in order to determine their level of ESL achievement, and first and second quarter grade reports were also collected for analysis. An evaluation and discussion of the research questions follows, along with a discussion of the strengths and limitations of the study, recommendations for future research, and implications for teachers and administrators. The chapter concludes with a summary. 
DISCUSSION OF RESEARCH QUESTIONS

The first question asked, "Which parental educational expectations and values are associated with their children's achievement in ESL acquisition?" As indicated in the Review of the Literature, researchers suggest that children whose parents possess a very high value for education and ultimate level of attainment may complete more schooling than children whose parents value education less (Laosa, 1983; Okagaki, et al., 1995; Trueba, 1988).

Several questions on the parent survey were designed to assess parental beliefs regarding educational expectations and values. As seen from the discussion in the previous chapter, the parents participating in this study hold a universally high value for educational attainment. These parents expected their children to complete college, regardless of how their children were performing in school at the time the questionnaire was completed. Whether this expectation of college completion is realistic remains to be seen. For future research, additional information regarding parental educational values and expectations might be secured by asking parents about their own desires for further education, as well as assessing how the parents performed when they were in school. Delgado-Gaitan (1991), Trueba (1988) and Clark (1983) contend that minority children, and language minority children in 
particular, fail to complete high school at a higher rate than dominant language, majority children. Nevertheless, ninety-five percent of the parents surveyed for this study disagreed with the statement "if my child works hard, he/she will not need a high school diploma to get a good job." It is apparent that the parents participating in this research project desire their children to obtain a complete education, which is consistent with the findings of other researchers (Clark, 1993; Goldenberg, 1987; Okagaki, et al., 1995).

Several scholars have emphasized the importance of parental discussion of 'core values' and relationship to student achievement and overall success in the dominant language society (Wong Fillmore, 1990; Caplan, et al, 1992). For this study, parents were asked to indicate how often they "talk about values or religious beliefs" with their child. Seventeen parents responded that they talk about values or religious beliefs "about once a week or more" while six parents indicated that discussion of this nature occurs "about once a month or less." Interestingly, parents who reported that they were less likely to elaborate on such matters had children who scored higher on the LAS-O $(p=0.0214)$. The results for the RMI on the same question were not statistically significant. This finding is contrary to that of other researchers. Possible explanations for this result were discussed in Chapter IV. 
The second research question asked, "Which parental behaviors (e.g. modeling of reading) are associated with their children's success in ESL acquisition?" Parents responded to several inquiries on the questionnaire regarding their behaviors or actions in the home environment, including modeling of reading and literacy-related activities. Eighty-three percent of the parents indicated that they assisted their children with homework three days or more in the week prior to answering the parent survey (see Table 5 in previous chapter). These findings support those of Okagaki, et al. (1995), in that parents of low achievers report assisting their children with homework just as often as parents of high achievers. In retrospect, however, one might question whether this information is truly quantifiable. A question which asks the parents if they set aside a specific time for their children to do homework in the evening, and if so, how many minutes they spend assisting their child, might provide a more accurate answer. Question 33 on the parent survey used for this study asked the parents to report how many days in the last week they assisted their child with schoolwork. Whether a parent helped their child for 5 minutes per day, or two hours per day, would be reported in the same category. Ninety percent of the parents reported reminding their children to study several times each week, and all of the parents indicated that they inquired about their children's 
progress in school more than once a week.

Fifty-six percent of the parents responded that they read a newspaper or magazine "about once a week or more." Their children were more likely to score greater than or equal to 80 on the RMI $(p=0.0823)$, and fifty-seven percent of the parents who claimed that they read a book themselves "about once a week or more" had children who scored greater than or equal to 80 on the RMI $(p=0.1158)$. However, similar trends were not observed on the children's scores on the LAS-O. The study conducted by Okagaki, et al. (1995) included a research sample of eighty-two participants. Their data regarding modeling of reading were statistically significant. Children of parents who read a magazine or newspaper with some frequency scored higher on reading proficiency measures.

The third question asked, "Is parental perception of efficacy (the degree to which parents of language minority children view themselves as being able to assist their children in school) related to their children's ESL and mainstream classroom achievement?" A review of the literature reveals that many researchers assert that parental perception of efficacy is a very important factor in student achievement (Wong Fillmore, 1990; Caplan, et al., 1992; Delgado-Gaitan, 1991; Okagaki, et al., 1995), and the findings of this research project support this view. 
Overall, fifty-three percent of the parents reported that they feel generally confident of their ability to help their child with homework. If parents responded that they feel generally confident in their ability to assist their child with schoolwork, their children were more likely to score 80 or greater on the RMI $(p=0.0376)$. The children of these parents also scored higher on the LAS-O, although the difference did not attain statistical significance ( $p=$ 0.0734). These results regarding parental perception of efficacy are consistent with Okagaki, et al. (1995).

As mentioned in chapter 3 , the first and second quarter grade reports for the students were collected for analysis in relation to parental perception of efficacy. Teachers at the research site school had the option of assigning one of three grades when evaluating students. Nearly all of the children received a grade of 2 ("making steady progress") on their first and second quarter transcripts. In other words, there was almost no variation to be found in the children's grade reports, making statistical analysis impossible.

Perhaps one explanation for the students' grades comes from this investigator's classroom observation. All of the teachers at the research site school are proficient in Spanish. Frequently, when a student did not appear to understand a lesson in English, the teacher offered assistance in Spanish. It is difficult to determine 
how accurately the grades reflect the students' comprehension and proficiency in English in this setting.

The final research question asked, "What demographic factors influence the Limited-English-Proficient (LEP) child's achievement in acquiring English?" Many scholars have focused on the disparity in academic performance among children from different minority groups enrolled in the American school system (Clark, 1983; Comer, 1984; Lareau, 1987; Trueba, 1988).

The parents and children who participated in this study share many similarities in their home environments. The demographic data collected for this project have been reported descriptively in the previous chapter, as not enough differences were found among the participants to analyze statistically. As shown in Figure 3 (in Chapter III), most of the parents are engaged in positions involving physical labor. Eighty-five percent of the parents who were employed worked twenty-one to forty hours a week or more. The parents have resided in the U.S. from five months (at the time the questionnaire was completed) to eighteen years, with seven and one-half years as the average length of residence.

\section{STRENGTHS AND LIMITATIONS}

One strength of this study is that there was no attrition among the participants: all of the children of each parent who 
completed the questionnaire were actually tested by the investigator. An additional strength of this research project is that the data generated corroborate the results of the study after which it was modeled.

Upon completion of the data analysis, several limitations of this study became apparent. The size of the sample (total number of parent and student participants) is small. The power of a study is directly related to the number of participants: the smaller the number, the less able the researcher is to define small differences in the responses. If this research sample were larger, then trends observed, such as how often parents obtain a library book or purchase a novel for themselves to read, might actually achieve statistical significance as found by Okagaki, et al. (1995).

In retrospect, a few questions on the parent survey were not designed well, and the responses given contradicted responses for other questions designed to address the same variable. One question simply had many more "blanks" than others. Marin and Marin (1991) indicate that among Hispanics, the ranges of missing data can vary "...from $1 \%$ to $6 \%$ depending on the type of instrument utilized (p. 109)." This range is higher than for non-Hispanic White populations. Additionally, Marin and Marin report that Hispanics most often choose the extremes when presented with a Likert-type response scale, such as was employed for the parent survey. As 
Marin and Marin note, the existence of this response style "can seriously affect the results of a study since the group variances and score correlations can be affected by these extreme response styles (p. 101)."

The use of a self-report instrument such as the one completed by the parent participants in this study has both strengths and limitations. Questions which are more open-ended, or which allow a variety of responses, may more accurately reflect what the respondent wishes to convey (Nunan, 1992). In using a questionnaire or survey, the researcher does not try to change the participants or their responses to specific variables in any way, but only collects data in a field setting regarding conditions, attitudes, behaviors, or events at a single point in time. Yet, the accuracy of responses on a self-report instrument can be an issue. Whether participants' answers reflect how they think the researcher wants them to respond, or whether they are a true indicator of a participant's beliefs, can at times be difficult to determine. However, self-report instruments remain a very effective tool in eliciting personal information from research subjects.

RECOMMENDATIONS FOR FUTURE RESEARCH Future research could focus on several areas, particularly 
parental perception of efficacy, and modeling of reading or literacy-related activities in the home. For a future study of this nature, a minimum sample size of seventy-five is recommended, so that results generated from the data may be more generalizable. In order to ensure that the reading proficiency of all children in a study can be assessed, future researchers may wish to include students in the upper primary grades, eliminating students in kindergarten or first grade who have not yet been taught to read. As Hewison (1988) demonstrates, it is important to quantify how often the parents listen to their child read aloud, as well as how often the parents read aloud to their children. With language minority populations, it is wise for the researcher to consider that literacy material may not often be available in the home. However, parents can still demonstrate literacy skills to their children by reading a recipe on a recipe card or by consulting a cookbook or dictionary, or by reading a letter sent by a family member still in the home country. Any instrument used with language minority populations should address these possibilities.

While the relationship between parental modeling of reading and reading proficiency of the child appears to be significant in many cases (Okagaki, et. al., 1995; Goldenberg, 1987; Laosa, 1983; Clark, 1990), the relationship between modeling of reading or other literacy activities and oral language proficiency is much less clear. 
Future research should address oral second language proficiency and any possible association with parental behaviors.

Another issue which could be addressed in subsequent research concerns the amount of television children watch per day. For this research project, parents were asked to comment on whether children were required to do homework before being allowed to play or watch television. All of the parents agreed strongly that homework must be completed first. For future studies, observation of parents and children in the home to assess schoolwork and television viewing policies might provide valuable data. It would also be interesting to determine whether the language in which children watched TV or listened to the radio, and the amount of time involved in that activity, impacted second language acquisition in any way.

Some questions emerge from this study in regard to the relationship between parental perception of efficacy and student achievement which could be explored in future research. Do parents experience a greater perception of efficacy because their children are doing well in school, or is their ability to assist their children at least partially responsible for their success? Can a parent's perception of efficacy actually be changed? One method of determining whether parental perception of efficacy can be changed would be to design a prospective study with two groups of students 
and parents, preferably at different schools. One group of students and parents would function as the control, and the other group would undergo the intervention. Each set of parents could be surveyed at the beginning of the study in regard to their parental perception of efficacy, and each group of students could be given a battery of achievement tests. A program designed for the parents in the experimental group to train them in techniques to assist their children's educational journey could be administered over a period of time. At the end of the trial period, both sets of parents would be retested in regard to parental perception of efficacy, and both groups of students would be retested on the achievement measures. The results of the pre-tests and post-tests could then be compared to determine if parental perception of efficacy positively affected students' performance.

\section{IMPLICATIONS FOR TEACHERS AND ADMINISTRATORS}

The primary implications of this study are that children of language minority parents who model reading in the home score higher on a test of reading proficiency than the children of parents who read less frequently. Furthermore, parental perception of efficacy appears to be an important factor in a child's English reading achievement.

Several researchers argue that it is the responsibility of 
teachers and administrators to initiate the involvement of language minority parents in the educational journey of their children (Bronfenbrenner, 1978; Comer, 1986; Epstein, 1987; SimichDudgeon, 1986, 1993). Due to the demands of careers and the pressures of raising a family, many parents of younger children delay their own reading or literacy activities until after their children are asleep. Parents should be encouraged to model reading in any language while their children are available to observe their behavior (Dolson, 1985; Caplan, et al., 1992; Laosa, 1983). School personnel may be able to contribute significantly to the development of language minority parents' perception of their ability to help their children succeed in an academic setting through parent training programs and frequent interaction among parents, teachers, school personnel, and respected members of the language minority community (Delgado-Gaitan, 1991; Laosa, 1983; Wong Fillmore, 1990). In addition, recognition by teachers and administrators of the 'core values' of language minority students and their families may inspire parental involvement and increase parental perception of efficacy (Simich-Dudgeon, 1986, 1993).

\section{SUMMARY}

In this quantitative study of thirty-six children enrolled in a public elementary school ESL program and their parents, several 
significant findings resulted. The data generated indicate that these language minority parents value education highly, expect their children to exert their best efforts in school, and that hard work without the benefit of a good education does not ensure success.

The results of this study are consistent with the research project after which it was modeled. Parental perception of efficacy appears to be an important factor in reading achievement, as well as parental modeling of reading. As Okagaki, et al., (1995) found in their study, parents of low achievers in this research project also reported assisting their children with homework just as often as the parents of the higher achievers, but the parents of children scoring higher on the RMI seemed more convinced that their assistance was effective. The Review of the Literature and the results of this study show that language minority parents have high hopes for the educational attainment of their children. Therefore, teachers and administrators may wish to promote specific behaviors such as parental modeling of reading, in either the heritage language or the second language. Educators must acknowledge that parents from economically and politically oppressed backgrounds possess skills and strengths which can benefit the educational process of their children. Such efforts to involve language minority parents may help to increase proficiency 
in the child's second language.

In the Review of the Literature, the notion of parents as coeducators of their children emerged (Potter, 1989; Epstein, 1987). Potter (1989) asserts that when parents act as coeducators, the benefits include more open communication among parents, schools, and communities, increased academic achievement of the schoolchildren, and a parental sense of pride and ownership in the educational process. If teachers and administrators can initiate involvement of language minority parents in the academic journey of their children, and increase parental perception of efficacy, perhaps more children in ESL programs will achieve proficiency in their second language. 


\section{REFERENCES}

Ada, A. F. (1993). A critical pedagogy approach to fostering the home-school connection. Washington, DC: ERIC Clearinghouse on Languages and Linguistics, Document Reproduction Services No. ED 358716.

Allexsaht-Snider, M. (1991). Family literacy in a Spanish-speaking context: Joint construction of meaning. The Quarterly Newsletter of the Laboratory of Comparative Human Cognition, 13 (1), 15-21.

Baker, C. (1992). Attitudes and Language. Multilingual Matters, Ltd., Clevedon

Baker, D. \& Stevenson, D. (1986). Mother's strategies for children's school achievement: Managing the transition to high school. Sociology of Education, 59, 156-166.

Becher, R. (1984). Parent Involvement: A review of research and principles of successful practice. National Institute of Education, Washington, D.C. ERIC Document Reproduction Service No: ED 247032.

Berryman, J. (1982). Importance of immigrant parents in their children's learning of a second language. TESL Talk, 14 (3), 25-30.

Blackie, J. A. (1991). Foreign language education: Winning through communications. Hispania, 74, 190-192.

Bloom, B. S. (1985). Developing talent in young people. New York: Ballantine Books.

Bronfenbrenner, U. (1978). Who needs parent education? Teachers 
College Record, 79, 767-787.

Caplan, N., Choy, M. \& Whitmore, J. (1992). Indochinese refugee families and academic achievement. Scientific American, February 1992, 36-42.

Caro, D. (1982). A family communication model for teaching English as a second language. Paper presented at the summer meeting of the Teachers of English to Speakers of Other Languages, Evanston, IL. ERIC Clearinghouse on Languages and Linguistics, Document Reproduction Services No. ED 224340.

Chavkin, N. F., \& Williams, D. L. (1987). Enhancing parent involvement: Guidelines for access to an important resource for school administrators. Education and Urban Society 19 (2), 164-184.

Clark, R. (1983). Family life and school achievement: Why poor black children succeed or fail. Chicago: University of Chicago Press.

Clark, R. (1990). Why disadvantaged students succeed: What happens outside of school is critical. Public Welfare, Spring (1990), 17-23.

Clark, R. (1993). Homework focused parenting practices that positively affect student achievement. In Chavkin, N. (Ed.) Families and schools in a pluralistic society, 85-105, Albany: State University of New York Press.

Cochran, M. \& Woolever, F. (1983). Beyond the Deficit Model: The empowerment of parents with information and informal supports. In I. E. Sigel \& L.M. Laosa, (Eds.) Changing Families, 225-245, New York: Plenum Press.

Collazo-Levy, D., \& Villegas, J. (1983). Project parents: Awareness, education and involvement. O.E.E. Evaluation Report, New York City Board of Education. Brooklyn, NY. 
Coleman, J. (1987). Families and schools. Educational Researcher, $16(6), 32-38$.

Comer, J. P. (1984). Home-school relationships as they affect the academic success of children. Education and Urban Society, 16 (3), 323-337.

Comer, J. P. (1986). Parent participation in the schools. Phi Delta Kappan, $\underline{67}$ (6), 442-446.

Cummins, J. (1986). Empowering minority students: A framework for intervention. Harvard Educational Review, $\underline{56}$ (1), 1836.

Davies, D. (1991). Schools reaching out: Family, school, and community partnerships for student success. Phi Delta Kappan, 2, 376-382.

De Avila, E. \& Duncan, S. (1990). Language assessment scales: Oral scoring and interpretation manual. CTB Macmillan McGraw-Hill, Monterey, CA.

Delgado-Gaitan, C. (1987). Parent perceptions of school:

Supportive environments for children. In H. Trueba (Ed.), Success or failure? Learning and the language minority student, 131-155, Cambridge, MA.: Newbury House.

Delgado-Gaitan, C. (1991). Involving parents in the schools: A process of empowerment. American Journal of Education, (1991), 21-46.

Dolson, D. (1985). The effects of Spanish home language use on the scholastic performance of Hispanic pupils. Journal of Multilingual and Multicultural Development. $\underline{6}$, (2), 135-155.

Eagle, E. (1989). Socioeconomic status, family structure, and parental involvement: The correlates of achievement. Paper presented at the Annual Meeting of the American Educational Research Association, San Francisco, March 27-31, 1989. 
ERIC Document Reproduction Services No.: ED 307332.

Epstein, J. L. ((1986). Parent involvement: Implications for limited-English-proficient parents. In C. Simich-Dudgeon (Ed.), Issues of parent involvement, Proceedings of the symposium at Trinity College (pp. 6-16). Washington, DC.

Epstein, J. L. (1987). Parent involvement: What research says to administrators. Education and Urban Society, 19, (2), 119136.

Figueroa, J. R. (1993). Can parental involvement and bilingual education save our language minority children from becoming disempowered and disenfranchised? Illinois School Journal, 72, (2), 40-49.

Fogiel, M. (1996). The statistics problem solver. New Jersey: Research and Education Association.

Gardner, R. (1968). Attitudes and motivation: Their role in second-language acquisition. TESOL Quarterly, (1968), 141150.

Gardner, R. (1985). Social psychology and second language learning. London: Edward Arnold.

Goldenberg, C. N. (1987). Low-income Hispanic parents' contributions to their first-grade children's word-recognition skills. Anthropology and Education Quarterly, 18, 149-179.

Goldenberg, C. N. (1989). Parents' effects on academic grouping for reading: Three case studies. American Educational Research Journal, 26, (3), 329-352.

Goodman, Y., Watson, D., \& Burke, C. (1987). Reading miscue inventory: Alternative procedures. New York: Richard C. Owen Publishers, Inc.

Goodz, N. S. (1994). Interactions between parents and children in 
bilingual families. In F. Genesee, (Ed.), Educating Second Language Children. 61-81, NY: Cambridge University Press.

Hansen, H. (1969). The impact of the home literary environment on reading attitude. Elementary English, 46, 17-24.

Hermann, G. (1980). Attitudes and success in children's learning of English as a second language: The motivational vs. the resultative hypothesis. English Language Teaching Journal, 34, (4), 247-254.

Hewison, J. \& Tizard, J. (1980). Parental involvement and reading attainment. British Journal of Educational Psychology, $\underline{50}$, 209-215.

Hewison, J. (1988). The long-term effectiveness of Parental involvement in reading: A follow-up of the Haringey project" British Journal of Educational Psychology (58), 184-190.

Hoffmann, C. (1991). An introduction to bilingualism. New York, Essex: Longman, Inc.

Kalinowski, A. \& Sloane, K. (1981). The home environment and school achievement. Studies in Educational Evaluation, 7 , 85-96.

Kellaghan, T., Alvarez, B., Sloane, K. \& Bloom, B. (1993). The home environment and school learning: Promoting parental involvement in the education of children. San Francisco: Jossey-Bass, Inc.

Lambert, W. E. \& Klineberg, O. (1967). Children's views of foreign peoples. New York: Appleton-Century-Crofts.

Laosa, L. (1983). School, occupation, culture and family. I. E. Sigel and L. M. Laosa (eds.), Changing families, 79-135, New York: Plenum.

Lareau, A. (1989). Home advantage: Social and parental 
intervention in elementary education. London: Falmer Press. Larsen-Freeman, D., \& Long, M. (1991). An introduction to second language acquisition research. London: Longman

Mayeske, G. W. (1973). A study of the achievement of our nation's students. U.S. Government Printing Office. Washington, DC.

Marin, G. \& Marin, B. (1991). Research with Hispanic populations. London: Sage Publications.

Nieto, S. (1985). Who's afraid of bilingual parents? Bilingual Review, 12 (3), 179-189.

Nunan, D. (1992). Research methods in language learning. Cambridge: Cambridge University Press.

Ogbu, J. U. (1991). Immigrant and involuntary minorities in comparative perspective. In Gibson, M. A. and Ogbu, J. U. Minority status and schooling: A comparative study of immigrant and involuntary minorities. New York: Garland.

Okagaki, L., Frensch, P. A., \& Gordon, E. W. (1995). Encouraging school achievement in Mexican American children. Hispanic Journal of Behavioral Sciences, 17, (2) 160-179.

Okagaki, L. \& Sternberg, R. (1993). Parental beliefs and children's school performance. Child Development, 64, 36-56.

Olmsted, P. (1991). Parent involvement in elementary education: Findings and suggestions from the follow through program. The Elementary School Journal, 91, 221-231.

Olmsted, P. \& Rubin, R. (1983). Linking Parent Behaviors to child achievement: Four evaluation studies from the parenteducation follow-through program. Studies in Educational Evaluation, 8 , 317-325.

Phillips, D. (1978). Basic statistics for health science students. New York: W. H. Freeman and Co. 
Potter, G. (1989). Parent participation in the language arts program. Language Arts, 66, (1), 21-28.

Ravid, R. D. (1987). The correlation of parents' and students' attitudes with Hebrew language achievement. Foreign Language Annals, 20, (5), 421-425.

Scott-Jones, D. (1984). Family influences on cognitive development and school achievement. Review of Research Education, 11, 259-304.

Silvern, S. (1985). Reading involvement and reading achievement: A review of research and implications for practice. Childhood Education, 62, (1), 44-49.

Silvern, S. (1988). Continuity/discontinuity between home and early childhood education environments. The Elementary School Journal. 89, (2), 147-159.

Simich-Dudgeon, C. (1986). Parent involvement and the education of limited-English-proficient students. Washington, DC: ERIC Clearinghouse on Languages and Linguistics, ERIC Document Reproduction Service No. ED 279205.

Simich-Dudgeon, C. (1993). Increasing student achievement through teacher knowledge about parent involvement. In Chavkin, N. (Ed.) Families and schools in a pluralistic society. 189-204, Albany: State University of New York Press.

Spolsky, B. (1969). Attitudinal aspects of second language learning. Language Learning, 19, 3 \& 4, 271-283.

Stevenson, D. \& Baker, D. P. (1987). The family-school relation and the child's school performance. Child Development, 58 , 1348-1357.

Tizard, J., Schofield, W. N. \& Hewison, J. (1982). Collaboration between teachers and parents in assisting children's reading. 
British Journal of Educational Psychology, 52, 1-15.

Torres, M. (1984). Parental attitudes toward language learning and bilingual education. Washington, DC: ERIC

Clearinghouse on Languages and Linguistics, ERIC Document Reproduction Services No. ED 245019.

Trueba, H. T. (1988). Culturally based explanations of minority students' academic achievement. Anthropology \& Education Quarterly, 19, 270-287.

Violand-Sanchez, E. (1991). Fostering home-school cooperation: Involving language minority families as partners in education. Washington, DC: National Clearinghouse for Bilingual Education, ERIC Document Reproduction Service No. ED 337018.

Wong Fillmore, L. (1990). "Now or later? Issues related to the early education of minority-group children" In Early childhood and family education: Analysis and recommendations of the council of chief state school officers New York: Harcourt Brace Jovanovich. 
APPENDIX A

INVITATION/FLYER SENT TO PARENTS 
MEETING: at Valencia Elementary School WHEN: Wednesday, January 31, 1996

PRIZE: Everyone who comes to the meeting will receive a new book in Spanish for their child.

REFRESHMENTS: juice, hot chocolate, and cookies will be provided PURPOSE OF MEETING:

* find out about tax information (IRS)

${ }^{*}$ meet Portland State University minority admissions representative (a native of Mexico)

${ }^{*}$ complete a parent questionnaire. Your responses in this questionnaire may assist teachers in their efforts to help Spanish-speaking ESL students be successful in school.

QUESTIONS: call Elena Vasquez (school number) 982-3991

(home number) 982-0978

\section{SEE YOU ON WEDNESDAY, JANUARY 31!}

REUNIÓN: En la Escuela Valencia Elementaria

CUANDO: $\quad$ Miercoles, 31 de Enero, 1996

PREMIOS: $\quad$ Cada persona que participe en la reunión recibirá un libro nuevo en Español.

REFRIGERIOS: Chocolate caliente, jugo, y galletas estarán proveidos. PROPOSITO DE LA REUNIÓN:

*Aprender información sobre los impuestos (IRS)

*Conocer a la representativa (nativa de Mexico) de inscripciones de la Universidad del Estado de Portland (Portland State University)

* Llenar un cuestionario para padres. Sus respuestas en el cuestionario podría ayudar a los maestros en sus esfuerzos de ayudar a los estudiantes que hablan español en el programa ESL para que ellos tengan éxito en la escuela.

PREGUNTAS:

llama a Elena Vasquez (numero en la escuela 982-3991)

(numero en la casa 982-0978)

¡NOS VEMOS MIERCOLES, 31 DE ENERO! 


\section{APPENDIX B}

CONSENT FORM 
I, agree to take part in this research project on parent attitudes about education for children in English as a Second Language (ESL) classes.

I understand that as a part of the study, I will be asked to complete a questionnaire, which will take about twenty to thirty minutes of my time. I understand that, because of this study, I will be giving up about one hour of my own time.

Catharine Jauhiainen has told me that the purpose of the study is to learn more about the relationship between attitudes of parents and how children learn English in the ESL classroom.

I may not receive any direct benefit from taking part in this study. But the study may help to increase knowledge for teachers of English, and may help other children in the future.

Catharine Jauhiainen has offered to answer any questions I have about the study and what I am expected to do. She has promised that all information I give will be kept confidential and that the names of all the people in the study will be kept confidential.

I understand that I do not have to take part in this study, and that I may withdraw from this study without affecting my relationship or that of my child with the school or the ESL teacher. I also give my permission for Catharine Jauhiainen to look at my child's (children's) November and February grade reports and the $\mathrm{RMI}$ and LAS-O test scores from ESL class.

I have read and understand the above information and agree to take part in this study.

Signature:

Date:

Name (s) of child (children) and ages:

If you have any concerns or questions about this study, please contact the Chair of the Human Subjects Research Review Committee, Research and Sponsored Projects, 105 Neuberger Hall, Portland State University, 503/725-3417. 
APPENDIX C

PARENT QUESTIONNAIRE--ENGLISH 
First, I would like you to think about how much education you want your child to have. Circle the number by the answer that best fits your opinion. Choose only one answer for each question.

1. How much education do you expect your child to get?

(circle only one answer) I think my child will:

1 finish junior high school (8th grade)

2 get some high school education

3 graduate from high school (12th grade)

4 go to a vocational school for job training

5 get some college education

6 graduate from college

7 get a graduate or professional degree (for example, become a doctor, lawyer, nurse, engineer)

2. What is the very least amount of schooling you would let your child get? (circle only one answer)

I won't let my child stop going to school until he/she:

1 finishes junior high school (8th grade)

2 gets some high school education

3 graduates from high school (12th grade)

4 goes to a vocational school for job training

5 gets some college education

6 graduates from college

7 gets a graduate or professional degree (for example, becomes a doctor, lawyer, nurse, engineer)

3. Do you feel that you are able to help your child do well in school? (circle only one answer)

1 I feel that there are many things I can do to help my child do well in school.

2 I feel there are some things I can do to help my child do well in school.

3 I feel there are a few things I can do to help my child do well in school.

4 I feel there is very little I can do to help my child do well in school. 
For the next questions, circle the number that shows how often you do the following activities. For each question,

$$
\begin{array}{ll}
1=\text { rarely or never } & \begin{array}{l}
4=\text { about once a week } \\
2=\text { about once a month or less }
\end{array} \\
\begin{array}{c}
5=\text { several times } \\
\text { each week }
\end{array} \\
3=2 \text { or } 3 \text { times a month } & 6=\text { daily }
\end{array}
$$
4. Get a library book or buy
123
45
6 book to read

5. Have child read a non-

$\begin{array}{llllllll}\text { school book at home } & 1 & 2 & 3 & 4 & 5 & 6\end{array}$

6. Remind child to study

$\begin{array}{llllll}1 & 2 & 3 & 4 & 5 & 6\end{array}$

7. Make child do homework before 1

$\begin{array}{lllll}2 & 3 & 4 & 5 & 6\end{array}$

8. Talk about values or religious beliefs with your child.

9. Read a book with your child.

1

10. Read a newspaper or magazine

11. Read a book yourself

12

23

456 (novel, religious book)

12. Take child to public library. $\begin{array}{llllllll}1 & 2 & 3 & 4 & 5 & 6\end{array}$

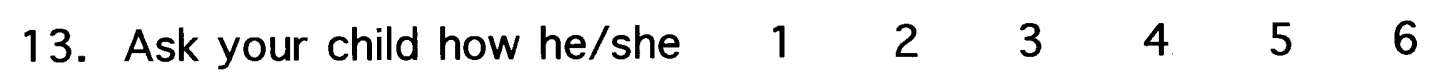
is doing in school.

In recent years schools have changed a lot. The work children do now can be very different from what parents did in school. I would like to know if you (or your spouse)feel you can help your child with his/her schoolwork. Circle the number that shows how you feel about helping with homework. 
14. If your child has a problem or question about his/her homework, do you feel that you (or your spouse) can help your child?

1 I feel very sure that I can help my child do his/her homework.

2 Most of the time I feel that I can help my child do his/her homework.

3 Sometimes I feel I can help my child, but sometimes I don't understand the work.

4 I usually do not feel that I can help my child do his/her homework.

15. Which statement best describes how you feel about parents helping children with their schoolwork?

1 I feel it is my child's job to do schoolwork on his/her own.

2 I feel it is my child's job to do the schoolwork but I offer help when he/she has a question or problem.

3 I feel that 1 should make sure that my child does his/her schoolwork and I should help when he/she has problems.

4 I feel that schoolwork should be done at school. It should not be brought home.

I would like to know your thoughts on raising children. You will probably agree with some of these statements and disagree with others. There are no right or wrong answers. Please tell me your honest opinions.

$$
\begin{aligned}
& 1=\text { strongly disagree } \\
& 2=\text { somewhat disagree } \\
& 3=\text { slightly disagree }
\end{aligned}
$$

$4=$ slightly agree

$5=$ somewhat agree

$6=$ strongly agree 
Please circle the number that represents your opinion.

16. My child will do well $\begin{aligned} & \text { DISAGREE } \\ & 1\end{aligned}$
if he/she learns to be
independent--to do
things on his/her own.
17. I want my child to be $1 \begin{array}{llllll}1 & 2 & 3 & 4 & 5 & 6\end{array}$ able to think and make decisions on his/her own.
18. My child can get a good job without finishing high school.

19. My child will be successful if he/she gets a high school diploma.

20. If my child works hard, he/she will not need a high school diploma to get a good job.

21. A good education is the $1 \quad 2 \quad 3$ $\begin{array}{lll}4 & 5 & 6\end{array}$ best way to get a good job.

22. To have a good education 1 23 $\begin{array}{lll}4 & 5 & 6\end{array}$ is more important than to have a lot of money.

23. Parents don't need to know 12 3 $\begin{array}{lll}4 & 5 & 6\end{array}$ where their child is if the child is playing with friends.

24. I expect my child to work $\begin{array}{lll}1 & 2 & 3\end{array}$ as hard as he/she can to get good grades in school. 
Finally, I would like to ask a few questions that will give me a description of you and your family. Circle the number or fill in the blank that shows your answer.

25. Your name:

26. Are you the child's mother or father?

1 Mother (or adult female the child lives with)

2 Father (or adult male the child lives with)

27. If you were not born in the United States, what is the name of your home country?

28. How long have you lived in the United States? years

29. What language(s) do you speak in your home?

30. What is the highest level of education you (and your spouse) have completed? Please circle the correct number.

\begin{tabular}{|c|c|c|}
\hline Mother & Father & \\
\hline 1 & 1 & No formal education \\
\hline 2 & 2 & Some grade school \\
\hline 3 & 3 & Completed grade school (8th grade) \\
\hline 4 & 4 & Some high school \\
\hline 5 & 5 & Completed high school \\
\hline 6 & 6 & Some vocational training/trade school \\
\hline 7 & 7 & Some college \\
\hline 8 & 8 & Completed college \\
\hline 9 & 9 & Some graduate work \\
\hline 10 & 10 & Graduate or professional degree \\
\hline
\end{tabular}

31. a. If the mother (or adult female the child lives with) is employed, what kind of job does she have?

(Example: electrical engineer, nurse, farmer, stock clerk)

b. What kind of business or industry is this job in?

(Example: retail shoe store, farm, hotel, manufacturing) 
32. a. If the father (or adult male the child lives with) is employed, what kind of job does he have?

b. What kind of business or industry is this job in?

33. How many days last week did you or your spouse help your child with his/her schoolwork? days

34. How much time did you and/or your spouse spend in a paid labor situation last week?

\begin{tabular}{lll} 
Mother & \multicolumn{2}{l}{ Father } \\
1 & 1 & $0-10$ hours a week \\
2 & 2 & $11-20$ hours a week \\
3 & 3 & $21-40$ hours a week \\
4 & 4 & OVER 40 hours a week \\
5 & 5 & Do not work outside of the home
\end{tabular}

35. Who does the child live with most of the time? (Circle one)

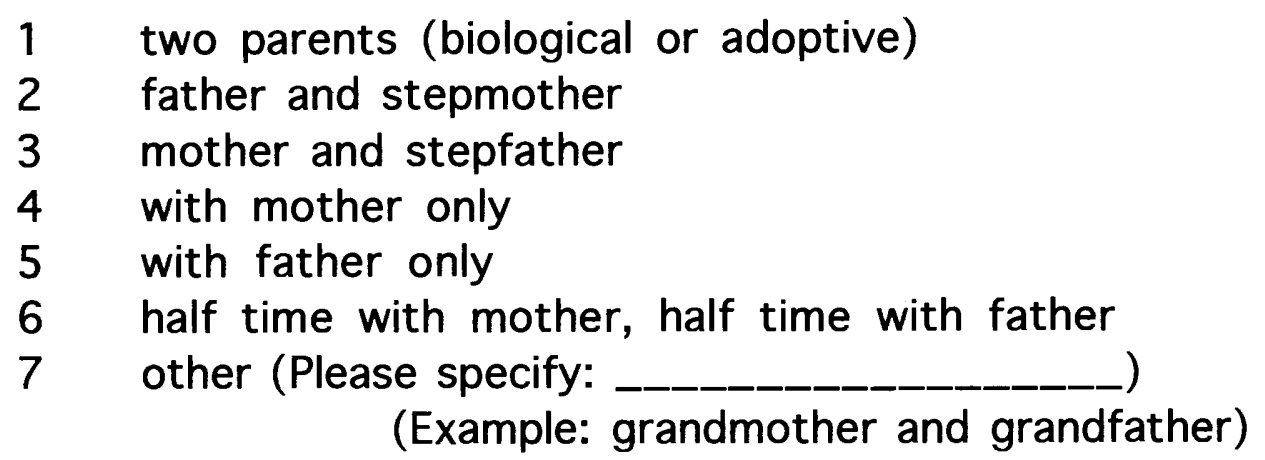

36. If there is a TV in the home, in what language do children watch TV?

37. Please fill in the information about the children in your family--each child's name, grade, year in school (example: 4th grade), age, sex (boy or girl), and the child's relation to you ( $1=$ biological child, $2=$ stepchild, $3=$ adopted child, or write relation, such as niece, grandchild, etc.) 
CHILD'S NAME GRADE AGE SEX RELATION TO YOU

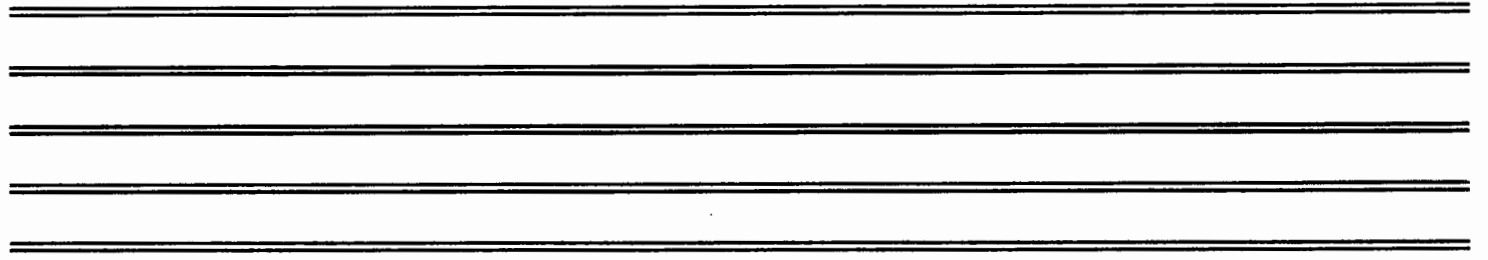


APPENDIX D

PARENT QUESTIONNAIRE--SPANISH 


\section{FORMADA DE CONSENTIMIENTO INFORMADO}

Yo, , estoy de acuerdo para tomar parte en este proyecto de investigación sobre las actitudes de los padres acerca de la educación para niños inscritos en clases de inglés como segundo idioma (ESL).

Yo entiendo que, como parte del estudio, me pedirán llenar un cuestionario, el cual me tomará de veinte a treinta minutos de mi tiempo. Yo entiendo que, a causa de este estudio, perderé como una hora de mi propio tiempo.

Catharine Jauhiainen me ha contado que el propósito de este estudio es aprender más sobre las relaciones entre las actitudes de los padres y cómo sus hijos aprenden el inglés en la sala de clase de ESL.

Puede ser que yo no reciba ningún beneficio directo por participar en este estudio. Pero el estudio podría aumentar el conocimiento de maestros de inglés, y podría ayudar a otros niños en el futuro.

Catharine Jauhiainen ha ofrecido contester cualquier pregunta que yo tenga sobre el estudio y sobre lo que esperan que haga. Ella ha prometido que toda la información que yo dé será mantenida en secreto, y que los nombres de todas las personas en el estudio serán mantenidos en secreto.

Yo entiendo que no tengo que participar en este estudio, y que puedo retirarme de este estudio sin afectar mis relaciones o las relaciones de mis hijos con la escuela o la maestra de ESL.

Además, yo doy permiso a Catharine Jauhiainen a mirar los reportes de calificaciones de mi niño(s) de noviembre y febrero y las calificaciones de los examenes RMI Y LAS-O de la clase de ESL.

Yo he leido la información ya mencionada y la entiendo, y estoy de acuerdo para tomar parte en este estudio.

Firme: Fecha:

Nombres de niños y sus edades:

Si tiene Ud. cualquier pregunta sobre esta investigación, llame al Human Subjects Research Review Committee, Research and Sponsored Projects, 105 Neuberger Hall, Portland State University, (503) 725-3417. 
Primero, yo quisiera que Ud. piense en cuanta educación quiere para sus hijos. Haga un círculo sobre el número al lado de la respuesta que mejor le parece. Escoge solamente una respuesta para cada pregunta.

1. ¿Hasta qué nivel de educación espera Ud. que sus hijos lleguen?

(Haga un círculo sobre solo una respuesta)

Pienso que mi hijo/hija va a:

1 alcanzar su octavo grado

2 lograr un poco de educación en la escuela secundaria

3 graduarse de la secundaria (doceavo grado)

4 asistir a una escuela vocacional para entrenamiento de trabajos

5 lograr un poco de educación en la universidad

6 graduarsede la universidad

7 lograr un título de graduado (por ejemplo, llegar a ser médico, licensiado, enfermera, ingeniero)

2. ¿Cuál es el mínimo de educación que permitiría Ud. que su hijo alcance? (Haga un círculo sobre solo una respuesta)

No voy a permitir que mi hijo/hija deje de asistir escuela hasta que él/ella:

1 alcance su octavo grado

2 logre un poco de educación en la escuela secundaria

3 se gradue de la secundaria (doceavo grado)

4 asista a una escuela vocacional para entrenamiento de trabajos

5 logre un poco de educación en la universidad

6 se gradue de la universidad

7 logre un título de graduado (por ejemplo, llegar a ser médico, licensiado, enfermera, ingeniero)

3. ¿Se siente capaz de ayudar a su hijo a tener éxito en la escuela?

(Haga un círculo sobre solo una respuesta)

1 Siento que hay muchas cosas que puedo hacer para ayudar en el éxito de mi hijo/hija en la escuela.

2 Siento que hay algunas cosas que puedo hacer para ayudar en el éxito de mi hijo/hija en la escuela.

3 Siento que hay unas cuantas cosas que puedo hacer para ayudar en el éxito de mi hijo/hija en la escuela.

4 Siento que hay muy poco que puedo hacer para ayudar en el éxito de mi hijo/hija en la escuela. 
Para las preguntas siguientes, haga un círculo sobre el número que demuestra cuantas veces que Ud. hace las actividades siguientes. Para cada pregunta,

$$
\begin{array}{ll}
1=\text { raramente o nunca } & 4=\text { una vez a la semana } \\
2 \text { = una vez al mes o menos } & 5=\text { varias veces a la semana } \\
3=\text { dos o tres veces cada mes } & \mathbf{6}=\text { diariamente }
\end{array}
$$

$\begin{array}{llllllllll}\text { 4. Conseguir un libro de la biblioteca } 0 & 1 & 2 & 3 & 4 & 5 & 6\end{array}$ comprar un libro para leer.

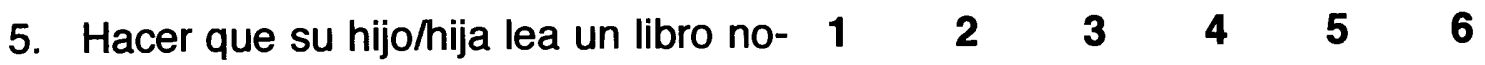
escolar en la casa.

6. Recordar al nino que estudie.

$\begin{array}{llllll}1 & 2 & 3 & 4 & 5 & 6\end{array}$

7. Hacer que el niño haga su tarea antes 1

$\begin{array}{lllll}2 & 3 & 4 & 5 & 6\end{array}$
de que él/ella tenga permiso a jugar o mirar la televisión.

8. Hablar de valores o creencias 1 religiosas con su hijo/hija.

9. Leer un libro junto con su hijo/hija. 1

2

3

456

10. Leer un periódico o revista.

$\begin{array}{llllll}1 & 2 & 3 & 4 & 5 & 6\end{array}$

11. Leer un libro Ud. mismo (novela, 12 3 libro religioso).

12. Llevar al niño a una biblioteca pública.

13. Preguntar a su hijo/hija cómo le va 1 2 3 45 6 en la escuela. 
En años recientes las escuelas han cambiado mucho. Las tareas que hacen los niños en la actualidad pueden ser bien diferentes de las que hacían sus padres en la escuela. Queremos saber si Ud. (o su esposo/esposa) siente capaz a ayudar a su hijo/hija con su tarea. Haga un círculo sobre el número que demuestra cómo Ud. siente en ayudar con tareas.

14. Si su hijo/hija tiene un problema o pregunta sobre su tarea, ¿se siente Ud. (o su esposo/a) capaz a ayudarlo/a?

1 Siento bien seguro/a que puedo ayudar a mi hijo/hija en hacer sus tareas.

2 La mayoría del tiempo siento seguro/a que puedo ayudar a mi hijo/hija en hacer sus tareas.

3 A veces siento que puedo ayudar a mi hijo/hija, pero a veces no entiendo la tarea.

4 Usualmente no me siento capaz a ayudar a mi hijo/hija hacer sus tareas.

15. ¿Cuál de las frases siguientes refleja mejor cómo Ud. siente de padres que ayudan a sus hijos hacer sus tareas?

1 Yo siento que es la responsabilidad de mi hijo/hija a hacer su tarea sin ayuda.

2 Yo siento que es la responsabilidad de mi hijo/hija a hacer su tarea, pero yo ofrezco ayuda cuando él/ella tiene preguntas o problemas.

3 Yo siento que debo asegurar que $\mathrm{mi} \mathrm{hijo/hija} \mathrm{haga} \mathrm{su} \mathrm{tarea} \mathrm{y} \mathrm{que} \mathrm{debo}$ ayudarlo/la cuando tiene problemas.

4 Yo siento que las tareas deben ser hechas en la escuela, no en la casa.

Quiero saber sus opiniones sobre la crianza de niños. Probablemente, Ud. 
estará de acuerdo con algunas de estas frases, y no con otras. No hay ninguna respuesta correcta o incorrecta. Por favor dígame sus opiniones honestamente.

$$
\begin{array}{ll}
\mathbf{1}=\text { fuertamente en desacuerdo } & \mathbf{4}=\text { apenas en acuerdo } \\
\mathbf{2}=\text { un tanto en desacuerdo } & \mathbf{5}=\text { un tanto en acuerdo } \\
\mathbf{3}=\text { apenas en desacuerdo } & \mathbf{6}=\text { fuertamente en acuerdo }
\end{array}
$$

Por favor haga un círculo sobre el número que representa su opinión.

$\frac{\text { NO ESTOY }}{\text { DE ACUERDO }}$

16. Mi hijo/hija tendrá éxito si aprende 1 a ser independiente-- a hacer las cosas por si mismo.

17. Quiero que mi hijolhija sea capaz de pensar y hacer decisiones por si mismo.

18. Mi hijo/hija puede conseguir un buen trabajo sin cumplir la secundaria.

19. Mi hijolhija tendrá éxito si se gradue de la secundaria.

20. Si mi hijolhija trabaja duro, no necesitará un diploma de la secundaria para conseguir un buen trabajo.

21. Una buena educación es la mejor manera de conseguir un buen trabajo.

22. Tener una buena educación es más 1 importante que tener mucho dinero.

23. Los padres no necesitan saber donde quedan sus hijos si están jugando con amigos.
ESTOY DE ACUERDO $\begin{array}{lllll}2 & 3 & 4 & 5 & 6\end{array}$

$\begin{array}{llllll}1 & 2 & 3 & 4 & 5 & 6\end{array}$

123

45

6

123

4

5

6

1

23

4

5

6

2

3

4

5

6

$\begin{array}{lllll}2 & 3 & 4 & 5 & 6\end{array}$

$\begin{array}{lllll}2 & 3 & 4 & 5 & 6\end{array}$ 1

1

3


tan duro como pueda para sacar

buenas notes en la escuela.

Por fin, quiero proponer unas preguntas que me darán una descripción de Ud. y de su familia. Haga un círculo sobre el número o llene el blanco que demuestra su respuesta.

25. Su nombre:

26. ¿Es Ud. la madre o el padre del niño?

1 Madre (o mujer adulta que vive con el niño)

2 Padre (o hombre adulto que vive con el niño)

27. Si Ud. es inmigrante, ¿cuál es el nombre de su país?

28. ¿Cuánto tiempo tiene Ud. en los Estados Unidos? años

29. Generalmente, ¿cuáles idiomas hablan Uds. en su casa?

30. ¿Cúal es el más alto grado de educación que han completado Ud. y su esposo/a? Por favor, haga un círculo sobre el número correcto.

\begin{tabular}{|c|c|c|}
\hline Madre & \multicolumn{2}{|c|}{ Padre } \\
\hline 1 & 1 & No educación formal \\
\hline 2 & 2 & Un grado de escuela primaria \\
\hline 3 & 3 & Completó el octavo grado \\
\hline 4 & 4 & Algo de la escuela secundaria \\
\hline 5 & 5 & Se graduó de la secundaria \\
\hline 6 & 6 & Algo de entrenamiento vocaciona \\
\hline 7 & 7 & Algo de la universidad \\
\hline 8 & 8 & Se graduó de la universidad \\
\hline 9 & 9 & Algo de educación graduada \\
\hline 10 & 10 & Título de graduado o profesional \\
\hline
\end{tabular}

31. a.Si la madre (o la mujer adulta que vive con el niño) trabaja, ¿qué clase de trabajo tiene?

(Por ejemplo: ingeniero, enfermera, agricultor, empleado en una tienda)

b. ¿En qué clase de negocio o industria está este trabajo?

(Por ejemplo: zapatería, hacienda, hotel, fábrica)

32. a. Si el padre (o el hombre adulto que vive con el niño) trabaja, ¿qué 
clase de trabajo tiene?

b. ¿En qué clase de negocio o industria está este trabajo?

33. ¿Cuántos días de la semana pasada ayudó Ud. o su esposo/a a su hijo con su tarea? días

34. ¿Cuánto tiempo pasó Ud. o su esposo/a trabajando por dinero la semana pasada?

\begin{tabular}{|c|c|}
\hline Madre & \\
\hline 1 & 7 \\
\hline 2 & 2 \\
\hline 3 & 3 \\
\hline 4 & 4 \\
\hline 5 & 5 \\
\hline
\end{tabular}

$0-10$ horas a la semana

11-20 horas a la semana

21-40 horas a la semana

Más que 40 horas a la semana

Yo no trabajo afuera de la casa

35. ¿Con quien vive su hijo/hija la mayoría del tiempo? (Haga un círculo sobre un número)

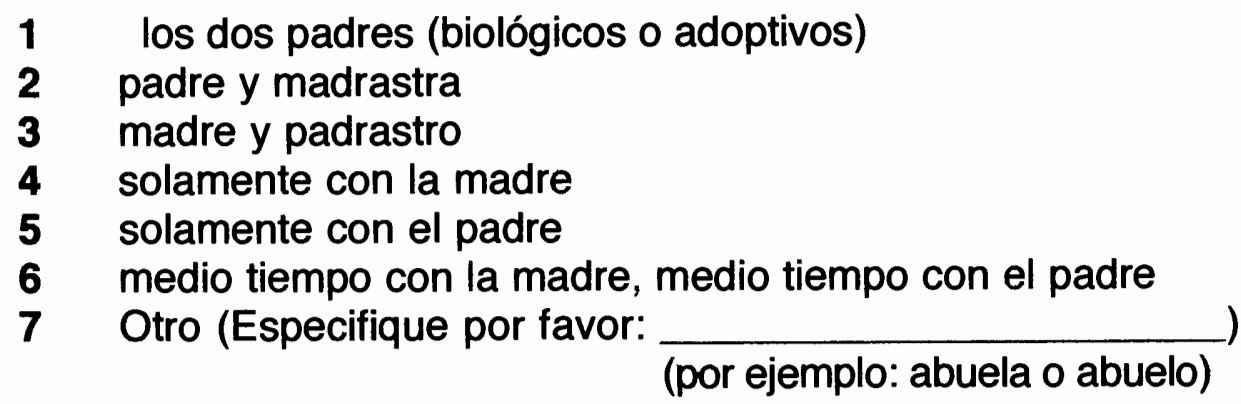

36. Si hay una televisión en la casa, ¿en qué idioma miran los niños la televisión?

37. Por favor llene la información sobre los niños de su familia--el nombre, grado o año en escuela (por ejemplo: cuarto grado), edad, sexo (niño o niña), y la relación del niño a Ud. ( $1=$ hijo biológico, $2=$ hijastro/hijastra, $3=$ hijo adoptivo, o escriba la relación, como sobrino, nieto, etc.)

NOMBRE DE NIÑO/NIÑA GRADO EDAD SEXO RELACIÓN 
APPENDIX E

SAMPLE READING MISCUE INVENTORY 
Sample Reading Miscue Inventory (RMI)

Monster Can't Sleep (Grade 2)

Student Date Grade

Teacher: "Start at the beginning and tell the story to me as if I have never heard it. Tell me every single thing you can remember." Encouraging words by the teacher throughout the retell might include: "You remember so much! Keep going and tell me more. You did a great job of remembering. Can you think of anything more you want to add?"

Check off items that the child includes in the retell. Do not ask specific questions about the text.

1. Characters and Description 115

2___Mother

2___Father

4___Monster

2___Spider 1___patient with Monster

1___patient with Monster

2___patient with Spider

1___does things his parents do

2. Events 140

7___Monster's bedtime and Monster can't sleep.

3___Father brings warm milk--doesn't work.

3_-_Mother reads story--doesn't work.

3___Mother and Father kiss monster--doesn't work.

3___Mother says good night.

3___Spider's bedtime.

3___Spider gets warm milk.

3 ____Spider gets story.

3 ____Spider gets kiss.

3___Monster says good night.

6 ___Monster falls asleep. 
3. Setting _-_/5

4. Plot

"Now that you've told me all about the story, please tell me in a few sentences what the story was about. Tell me the way you would tell a friend who asks what the book is about."

Child's Response:

5. Theme

"What do you think the author (the person who wrote the story) is trying to teach us with this story?"

SOME POSSIBLE THEMES:

Sometimes is takes a long time to fall asleep.

It helps to fall asleep if you have a stuffed animal.

Using your imagination helps you to get to sleep.

Special attention helps you get to sleep.

Sometimes you have trouble falling asleep even with special attention.

Parents like you to get enough sleep.

Child's Response:

6. Total Retell Score

7. Overall Retell Comments:

8. Recommendations for Instruction: 


\section{Monster Can't Sleep}

by Virginia Mueller

Monster was playing with his stuffed spider.

"It's bedtime," said Mother.

But Monster wans't sleepy.

Father gave Monster some warm milk.

But Monster wasn't sleepy.

Mother read Monster a bedtime story.

But Monster wans't sleepy.

Mother and Father kissed Monster good night.

But Monster wasn't sleepy.

"It's time for bed," said Mother. 'Good night!"

"It's bedtime for Spider, too," said Monster.

He brought Spider some warm milk.

He told Spider a story.

He gave Spider a kiss.

“Good night, Spider," said Monster.

Then Monster went to sleep. 